\title{
Back-arc basin origin for the basalts of the South Andaman Island Ophiolite (India)
}

\author{
Department of Geology, University of Delhi, Delhi -110007, India; *Corresponding author, E-mail: ashima.saikia@gmail.com
}

(Received: June 25, 2020; Revised accepted: January 6, 2021)

https://doi.org/10.18814/epiiugs/2021/021001

Petrological, mineral chemical and geochemical characteristics are reported for the basalts of South Andaman ophiolite suite (India) of Cretaceous age to infer its petrogenesis, magma source characteristics and tectonic setting. In the field, both massive basalts and basalts with wellpreserved pillow morphology are present. The basalts consist of plagioclase, clinopyroxene, Fe-Ti oxide and Cr-spinel. They are tholeiitic in composition with low concentrations of $\mathrm{Na}_{2} \mathrm{O}+\mathrm{K}_{2} \mathrm{O}$ (3- $\left.5 \mathrm{wt} . \%\right)$. The representative samples of these basalts have a nearly flat chondrite-normalized REE pattern $\left[(\mathrm{La} / \mathrm{Yb})_{N}=0.29\right.$ - 2.27)] with minor Eu anomaly $\left(E u / E u^{*}=0.90-1\right)$. Our findings suggest that the arc-like massive basalts were generated before the back-arc rifting initiated in an earlier stage of back-arc extension as a result of eastward subduction of the Neotethyan oceanic slab. The MORB-like pillow basalts were erupted due to further back-arc spreading in response to the roll-back of the Neotethyan oceanic lithospheric slab. The pillow and massive basalts assemblage in the South Andaman ophiolite records the evolution of a back-arc basin from initial rifting to subsequent spreading, documenting how basaltic magmatism evolves during the formation of the back-arc basin in a suprasubduction zone setting.

\section{Introduction}

Ophiolites are preserved allochthonous segment of oceanic crust which evaded destruction or lithospheric consumption. It got incorporated onto the continental margin either due to continent-continent or arc-continent collisions (e.g., Dilek and Flower, 2003), ridge-trench interactions (e.g., Cloos, 1993; Lagabrielle et al., 2000), and/or subduction-accretion events (e.g., Cawood et al., 2009). The geological records of the evolution of ocean basins from rift-drift and seafloor spreading to initiation of subduction and final closure are often well preserved in most orogenic belts. Magmatism during each of these phases are related to separate melting episodes and processes of magmatic differentiation in specific tectonic environments, which produce spatially and temporally associated, mafic-ultramafic to highly evolved rock assemblages (ultramafic tectonite commonly serpentinized harzburgite, cumulate mafic- ultramafic rocks, non-cumulate gabbros, sheeted dolerite dykes, and basaltic pillow lavas overlain by the pelagic sediments). These rocks with varying internal structures, geochemical affinities, age range which forms in different geodynamic settings are the ophiolite suite.

Ophiolites were initially considered to represent the mid-oceanic ridge (MOR) system (e.g., Nicolas, 1989). However, workers like Miyashiro (1973) and Shervais (1982) suggested diverse tectonic origin that includes fore-arc, back-arc and island-arc settings. Their geochemical signatures, internal structure and thickness are known to vary with spreading rate, proximity to plumes or trenches, mantle temperature, mantle fertility and the availability of fluids during primary igneous activities (e.g., Dilek and Furnes, 2011, 2014). The occurrence of ophiolite generally marks the boundary between amalgamated plates or accreted terranes (Dilek, 2003) in both collisional-type (e.g., Alpine, Himalayan, Caledonides, Appalachian) and accretionary-type (e.g., West Pacific, North American Cordilleran) orogenic systems (e.g., Gray et al., 2000; Dilek 2003; Wakabayashi and Dilek, 2003; Lister and Forster, 2009).

India's collision with Eurasia is a well-studied zone of continentcontinent collision. The Indus-Yarlung Tsangpo suture zone (IYTSZ) marks the location of remnants of the once extensive Mesozoic-age Tethyan Ocean, which formerly lay between India and Asia. This suture extends west to east from Pakistan and NW India across southern Tibet and wraps in a clockwise direction around the "eastern Himalayan syntaxis" of Namcha Barwa. After this, the suture turns to the south. The continuation of the Tethyan boundary is marked by a line of ophiolite occurrences east of the present-day plate boundary through the IndoBurma ranges (IBR) southward toward the Andaman Islands (Acharyya, 2010, 2015; Baxter et al., 2011; Sloan et al., 2017, Aitchinson et al., 2019) (Fig. 1).

The South Andaman Island is a part of the Andaman Islands located in the south-eastern fringe of the Indian plate margin, which is tectonically associated with the Indonesian arc system and contains several Mesozoic- age ophiolitic exposures (Hamilton, 1978). The Late Mesozoic to Early Cenozoic Andaman ophiolite, belonging to the western belt of Indo Burma Ridge (IBR), preserves a complete ophiolite sequence towards the outer arc of active Burma-Andaman-Java subduction zone. Andaman ophiolite comprises of a basal serpentinized and tectonized mantle peridotite unit overlain by ultramafic and mafic cumulate units, basaltic dykes and pillow basalts (Saha et al., 2010). Limited work has been carried out on the various segments of the exposed rocks which include cumulates of ultramafics (serpentinite/dunite, harzbur- 


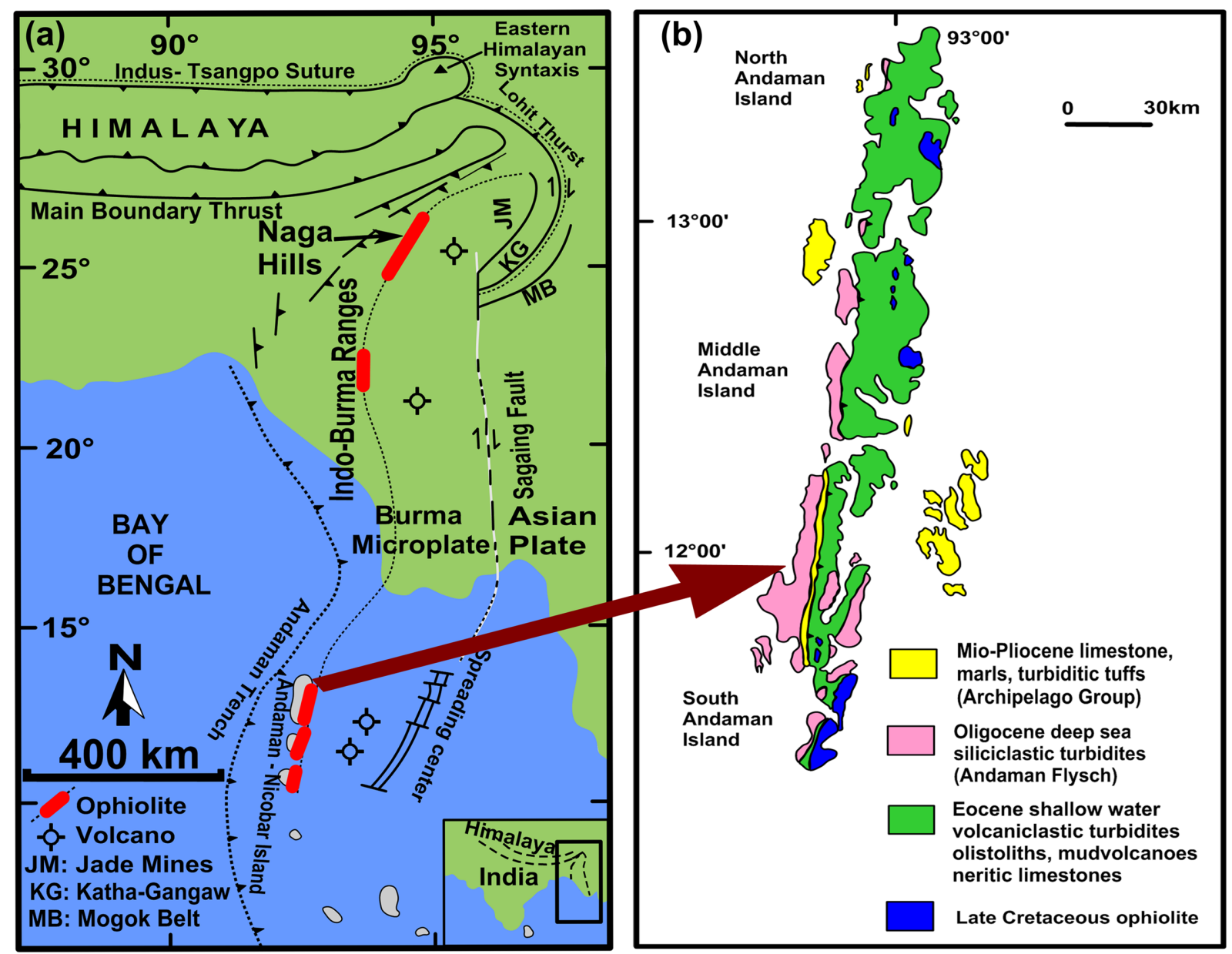

Figure 1. (a) Generalized tectonic map of the eastern margin of India and the plate boundary interactions between India, Burma and Sunda. Also shown are the Eastern Himalayan Syntaxis of Himalaya, the eastern end of the Indus-Sangpo suture zone, the seafloor spreading system in the Andaman back-arc basin, and the Nagaland-Manipur Hills ophiolite belt as the Southern continuation of the Indus-Sangpo suture zone (modified after Fareeduddin and Dilek, 2015). (b) Generalized geological map of the Andaman Islands showing the distribution of the ophiolite and sedimentary units with their stratigraphic relationship and tectonic setting after Pal et al., (2003).

gite and spinel lherzolite) (Saha et al., 2010; Pal, 2011; Bhattacharya et al., 2013; Saha et al., 2018), mafic rocks gabbro - (Shastry et al., 2002; Saha et al., 2010; Pal, 2011; Ghosh et al., 2014; Rasool et al., 2015), troctolite - (Ghosh et al., 2014) and pillow lavas - (Ray et al., 1988; Vohra et al., 1989; Jafri et al., 1990; Jafri and Charan, 1992; Jafri et al., 1995, 2006, 2010; Srivastava et al., 2004; Jafri and Sheikh, 2013; Bhattacharya et al., 2013; Ghosh et al., 2017; Sachin and Pal, 2017; Bandyopadhyay et al., 2020), felsic rocks plagiogranite - (Jafri et al., 1995; Pedersen et al., 2010; Sharma et al., 2010) and sedimentary radiolarian cherts (Jafri, 1986; Haldar, 1984; Jafri et al., 1993; Ling et al., 1996; Pal et al., 2003; Jafri et al., 2020).

Despite limited work available on the complete suite of Andaman island ophiolite, its basaltic rocks have been the most extensively studied section. Various concepts have been proposed over the years about the origin of these basaltic rocks. Some of the ideas include N-MORB, island-arc and back-arc tectonic settings (e.g., Srivastava et al., 2004; Jafri et al., 2010; Pal, 2011; Jafri and Sheikh, 2013; Ghosh et al., 2017).

We present a detailed study on petrography, mineral composition of constituent phases and bulk rock geochemistry of pillow and massive basalt occurrences of the South Andaman Island ophiolite. It will contribute to our understanding of their petrogenesis, magma source character- istics and tectonic environment that prevailed during their genesis. These findings have important implications for illustrating the ophiolite genesis in the Burma-Andaman-Java subduction zone.

\section{Geological Setting}

The Andaman Island in the Bay of Bengal is a part of the Andaman-Nicobar ridge, which is an accretionary prism complex of the outer-arc ridge of the active Sunda subduction zone (Allen et al., 2007). Tectonically, Andaman island chain can be divided into two major elements, an outer-arc comprising the ophiolitic crust and trench sediment and a forearc comprising siliciclastic and carbonate turbidites (Ghosh and Bhatta, 2014). The geological units of this island are classified into four groups: (1) Cretaceous Ophiolite Group, (2) Mithakhari Group, (3) Oligocene Andaman Flysch Group and (4) Mio-Pliocene Archipelago Group. The ophiolitic rocks of this island form the basement. Ophiolitic rocks are overlain by the Mithakhari Group, Andaman flysch Group and Archipelago group. The ophiolite suite is dismembered and comprises of harzburgites, cumulates (dunites, wherlites, pyroxenites, gabbro and plagiogranites) and massive and pillow basalts overlain by 
pelagic sedimentary sequence along with volcanic-sedimentary series (Pal et al., 2003; Saha et al., 2010).

The age of Andaman ophiolites and the timing of their obduction is still controversial. Recently, two independent groups of researchers dated zircon from plagiogranites of the Ophiolite Group from south Andaman by U-Pb dating method and suggested that their formation could not have been younger than $~ 95 \mathrm{Ma}$ (Pedersen et al., 2010; Sharma et al., 2010). The new age reported by these studies for Andaman ophio- lites is similar to the age of Oman and Troodos and Cyprus ophiolites. Their findings indicated that the Andaman ophiolites might be an extension of the range of Late Cretaceous ophiolite formation along the Tethyan suture zones from the Mediterranean to the Andaman Sea. The similarity in age between the Troodos, Oman and the Andaman ophiolite seems best explained by a supra-subduction zone origin (Pal, 2011). However, Plunder et al. (2020) suggest a relatively older age of about $106.4 \pm 2.1 \mathrm{Ma}$ and 105.3 $\pm 1.6 \mathrm{Ma}$ for amphibolite rock from the

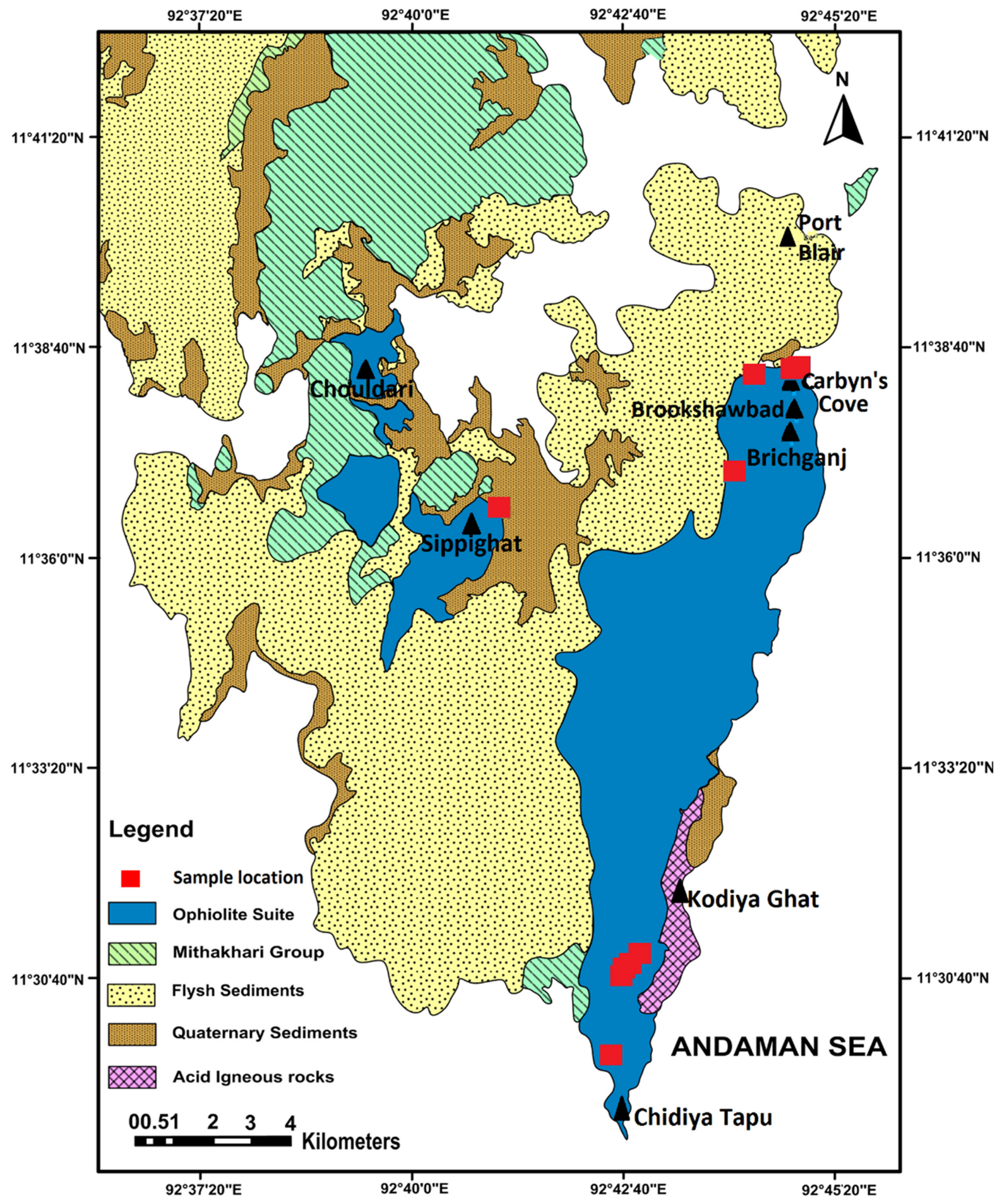

Figure 2. Map of the South Andaman Island after Bhat et al., (2019), with georeferenced sample locations of basalts marked in red squares in South Andaman Ophiolite. 
metamorphic sole of the Andaman Ophiolites. They adopted the $\mathrm{Ar} / \mathrm{Ar}$ method on amphibole. They argue for an arc-continent collision during the Cretaceous for the origin of the Andaman ophiolites.

\section{Sampling and Analytical Methods}

For petrographic and chemical analyses, samples were collected from the South Andaman Island Ophiolite suite exposures located in the backyard of Chatham Saw Mill, Corbyn's Cove, Chiriyatappu Crossing, Chouldari and Brichganj localities (Fig. 2). Massive lavas predominate over pillow lavas. In only two localities (Corbyn's Cove and Brichganj) we could find preserved pillows. Basaltic pillows are circular to elliptical in morphology (Fig. 3a-b). The outcrops occur as fine-grained dark massive bodies in association with mafic-ultramafic rocks (Fig. 3c-d).

Microprobe analyses were performed in six representative polished thin sections of basalts of the South Andaman Ophiolite. Mineral compositions were determined using a Cameca SX 5 Electron Probe Micro Analyzer at the Department of Earth Sciences, IIT Mumbai (India), with accelerating voltage $15 \mathrm{kV}$, specimen current of $20 \mathrm{nA}$ and beam diameter of $\sim 1 \mu \mathrm{m}$ (peak: $10-20 \mathrm{sec}$ and back-ground counting:
5-10 sec). Minerals, as well as synthetic phases, were used as standards. Duplicate analysis of individual points shows an analytical error of less than $1 \%$. The PAP correction was applied to the raw data (Pouchou and Pichoir, 1987).

A total of 17 selected samples were analyzed for the whole rock major and trace elements, of which five are pillow basalt and twelve are massive basalts. Major oxides and trace elements were analyzed using X-ray fluorescence (Bruker S8 Tiger Sequential X-ray Spectrometer with an Rh excitation source) following the procedure of Saini et al., $(1998,2000)$. Rare earth elements (REE) were measured using Inductively Coupled Plasma Mass Spectrometry (ICP-MS) (Perkin Elmer made SCIEX quadrapole type ICP-MS, ELAN DRC-e) at the Wadia Institute of Himalayan Geology, Dehradun (India). Operating conditions for the major oxides were: no filter, vacuum path, $20 / 40 \mathrm{kV}$; for trace elements: no filter, vacuum path, $55 / 60 \mathrm{kV}$. Internal standards UBN, AMH was used for XRF data calibration. The relative standard deviation (RSD) was $<5 \%$ for the major and minor oxides, and $<12 \%$ for the trace elements. The average precision is better than $2 \%$ (Purohit et al., 2006; Saini et al., 2007). For REE analysis sample solutions were introduced into the argon plasma using a peristaltic pump and a cross-flow nebulizer. The procedures adopted for sample digestion and preparation of solutions were that of Balaram et al., (1990). The United States
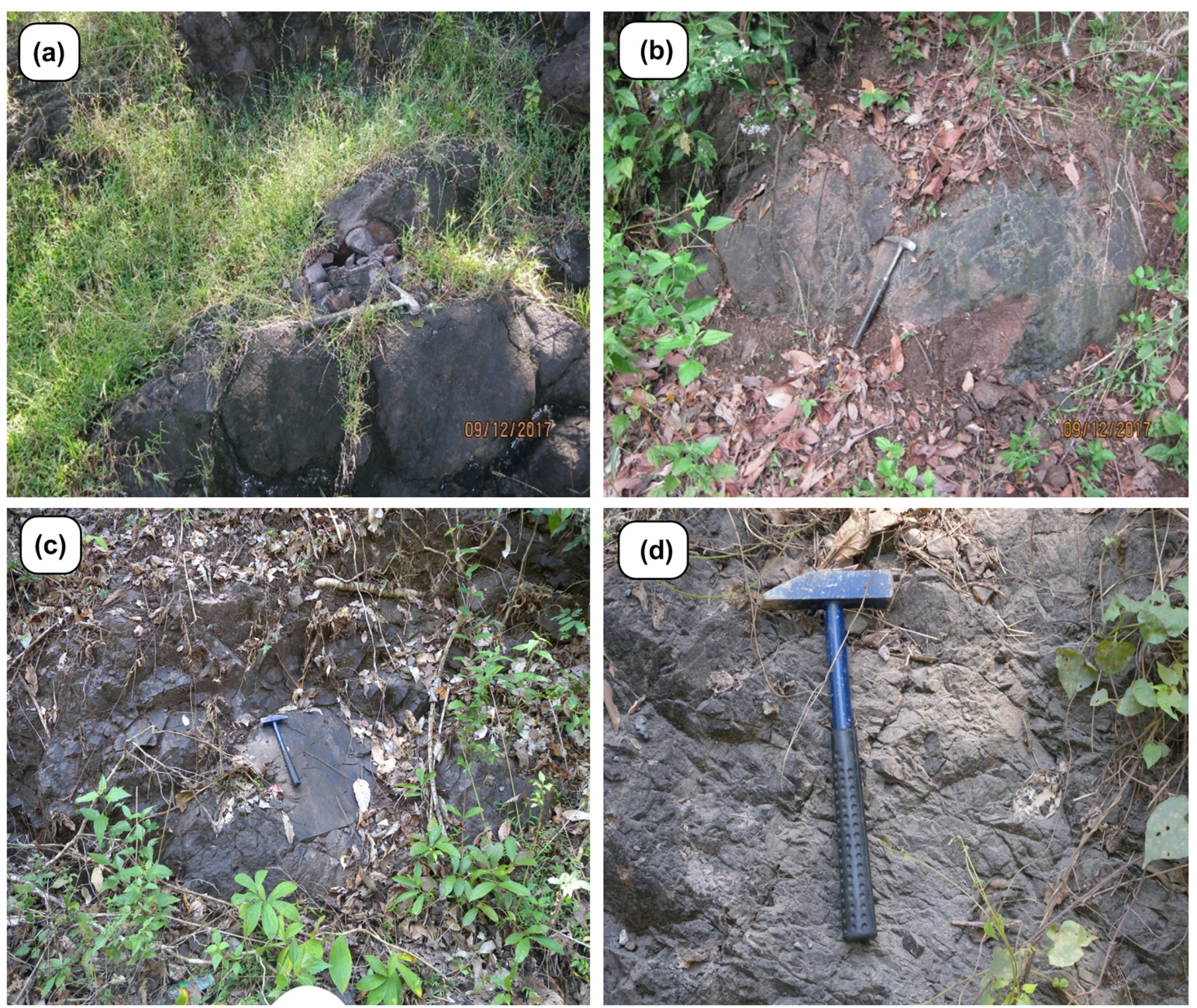

Figure 3. Field photographs from the South Andaman Ophiolite belt displaying (a-b) pillow basalt (c-d) massive basalts occurrences from different

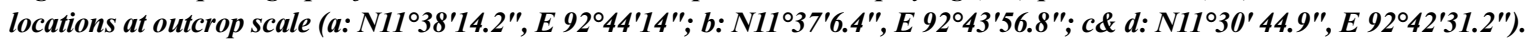


Geological Survey (BHVO-1) and the Geological Survey of Japan (JBI1a) samples were used as rock standards to minimize matrix effects. The RSD for most of the samples was $<10 \%$.

\section{Results}

\section{Petrography}

The South Andaman ophiolite extrusives comprise of pillow and massive lavas. These two groups are indistinguishable in petrographical observation. They consist of euhedral plagioclase phenocryst, set in a microlitic to intersertal groundmass composed of plagioclase, clinopyroxene, Fe-Ti oxides, spinel and accessory apatite, chlorite and epidote disseminated in microlitic matrix (Fig. 4). Igneous plagioclases are altered to albite with minor sericite, calcite and epidote, and therefore these extrusives may be classified as spilites. Clinopyroxenes show two stages of alteration. Some clinopyroxenes show deuteric alterations to amphiboles, and are partly hydrothermally altered to chlorite and epidote in the both petrological groups. Despite minor alterations, igneous textures are well preserved in all samples.

Texturally, massive lavas are mostly plagioclase-phyric and show fine-grained intergranular and intersertal texture. Amygdales filled with calcite and chlorite are quite common in massive basalts, thus suggesting relatively shallow water effusion. The pillow lavas are also plagioclase- phyric or plagioclase-clinopyroxene-phyric. The pillows display plumosevariolitic to hypocrystalline porphyric texture. Calcite and/or chlorite filled amygdaloidal pillow lavas are rarely observed.

Petrographical evidence in the basaltic extrusives suggests the following order of crystallization: plagioclase $\rightarrow$ clinopyroxene + plagioclase $+\mathrm{Fe}-$ Ti oxide. Additionally, in massive basalt samples, spinel coexists with the early fractionated plagioclase whilst rare Fe-Ti oxides are confined in the matrix.

\section{Systematic Mineralogy of the Basalts}

\section{Plagioclase}

Results of mineral analyses of plagioclase and the calculated number of cations per unit cell from the basaltic extrusives of Andaman ophiolite are given in Supplementary Table S1. According to the classification of Smith (1974a, b) plagioclase in the Andaman Ophiolite ranges from sodic-calcic to more sodic compositions. The anorthite content varies from $\mathrm{An}_{0}$ to $\mathrm{An}_{32}$ with compositions ranging from oligoclase to albite for the microphenocrysts of plagioclase in the pillow basalts. For the massive basalts, the plagioclase microphenocrysts and phenocrysts show varied content of $\mathrm{An}_{1-57}$ showing compositions ranging from labradorite to albite (Fig. 5a). The plagioclase phenocryst of the studied basalts does so compositional zoning in few grains. The core compositions of the phenocrysts are relatively calcium-rich, whereas
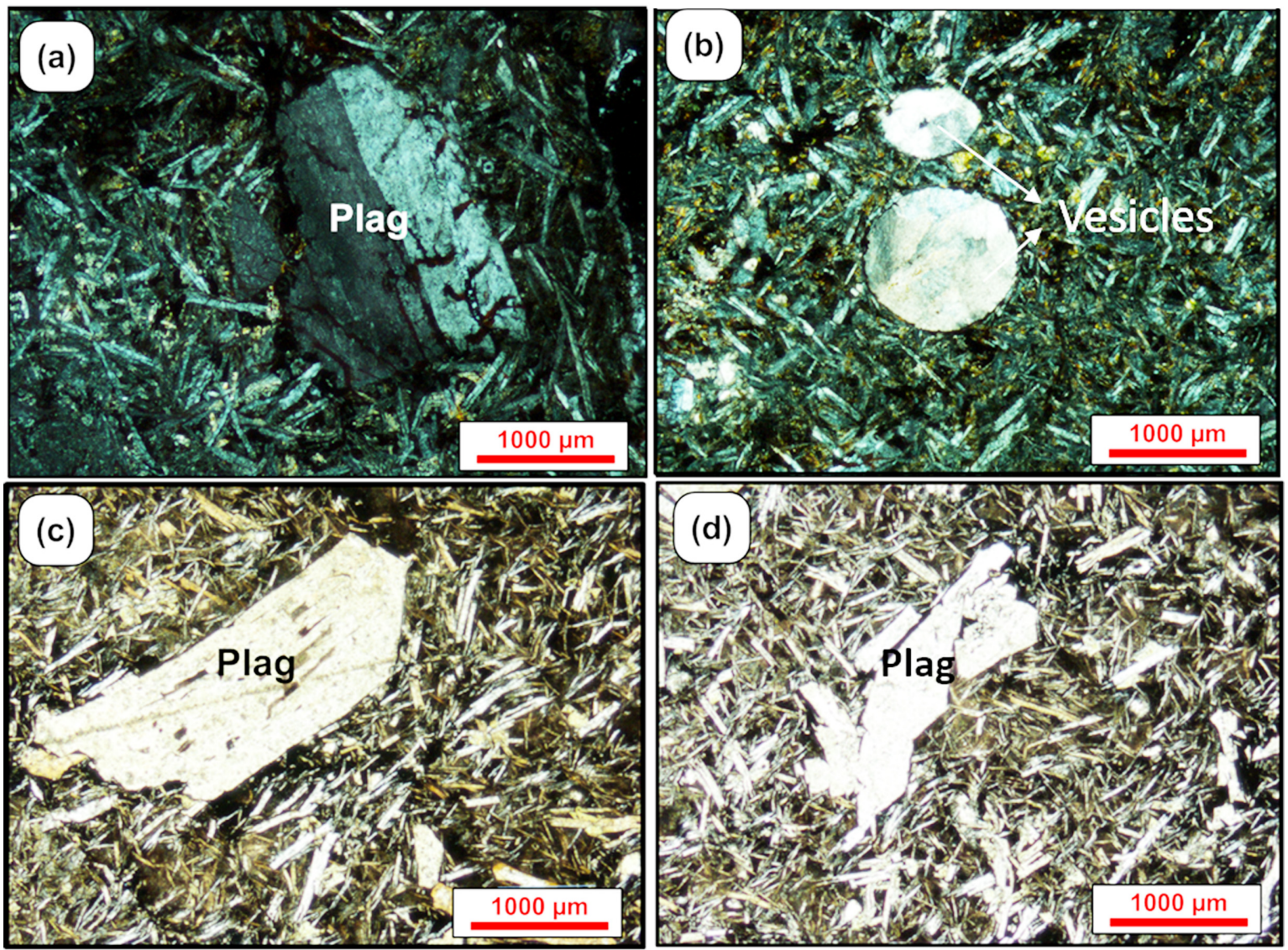

Figure 4. Photomicrographs of the basalts of South Andaman Ophiolite (a-b: massive basalt showing phenocryst of feldspar set in microlitic to intersertal matrix of clinopyroxene and plagioclase and vesicles filled by secondary minerals; $c$-d: pillow basalt showing phenocrysts of feldspar in microlitic matrix of plagioclase and clinopyroxene.) (Abbreviations: Plag = plagioclase). 

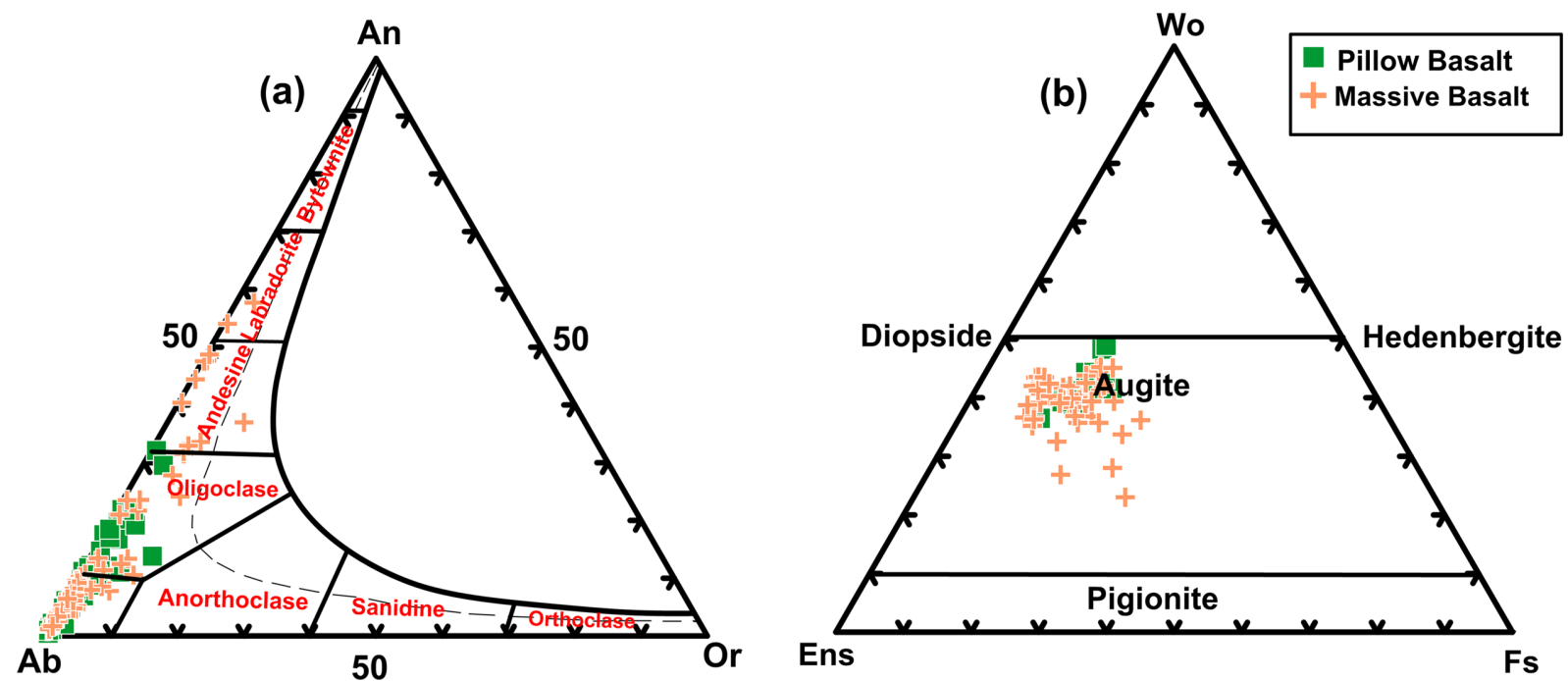

Figure 5. (a) Nomenclature of plagioclase occurring in the basalts of South Andaman Island ophiolite. (b) Pyroxene quadrilateral after Morimoto et al., 1988, showing the composition of clinopyroxenes of the basaltic extrusives from the South Andaman Island Ophiolite.

the rims are mostly albitic. Microphenocrysts in the matrix of massive basalts are mostly of albitic composition. Presence of albite indicates albitization as a result of deuteric alteration.

\section{Pyroxene}

The compositions of representative clinopyroxenes are listed in Supplementary Table S2. Clinopyroxenes of the basalts are augite, according to the classification of Morimoto (1989) (pillow basalt: $\mathrm{Wo}_{61-39}$, $\mathrm{En}_{35-51}, \mathrm{Fs}_{15-19}$; massive basalt: $\mathrm{Wo}_{35-44}, \mathrm{En}_{36-52}, \mathrm{Fs}_{7-26}$ ) (Fig. 5b) with $\mathrm{Mg} \#=$
65-84, $\mathrm{TiO}_{2}=2-0.34$ wt.\% and $\mathrm{Na}_{2} \mathrm{O}=0.32-0.68$ wt.\% $\left(\right.$ Table $\left.\mathrm{S}_{2}\right)$. Clinopyroxenes are homogeneous in composition, indicating their crystallization in a stable environment with the maintained condition and melt composition. Studies by Leterrier et al. (1982) and Beccaluva et al. (1989) have categorically shown that composition of clinopyroxene is sensitive to the magmatic affinity of basalts and can be used to ascertain different tectonic settings in which they were crystallized. Composition of clinopyroxenes is dependent on the composition of magmas from which they crystallize in addition to being controlled by crystal-chemical constrain. The clinopyroxenes from the pillow and
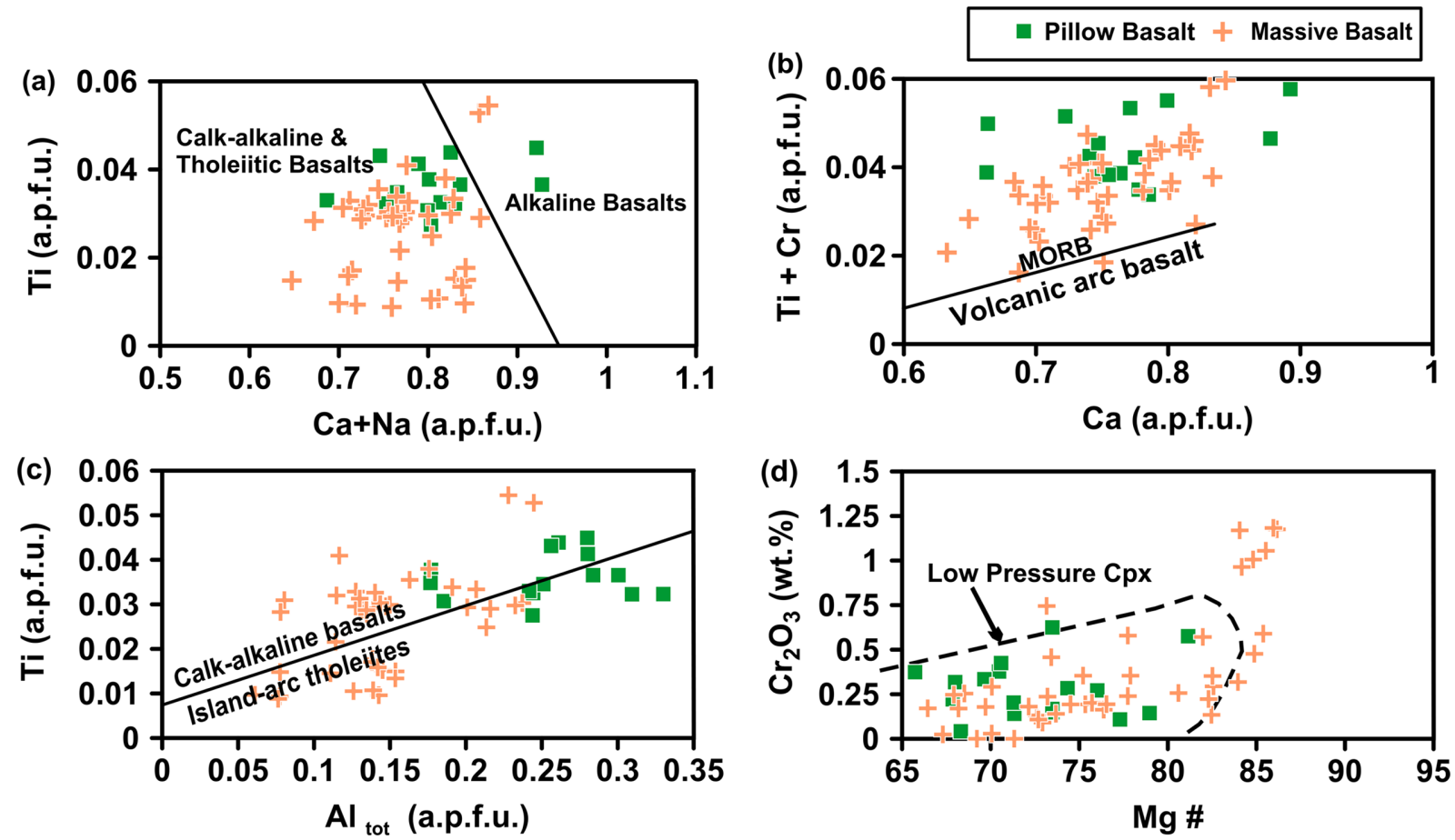

Figure 6. (a) Ti vs. (Ca $+\mathrm{Na})$, (b) $(\mathrm{Ti}+\mathrm{Cr})$ vs. $\mathrm{Ca}$, and (c) Ti vs. Al tot discrimination diagrams of Leterrier et al. (1982) showing the composition of clinopyroxenes from pillow lavas and massive basalts from the South Andaman Island ophiolites. (d) $\mathrm{Cr}_{2} \mathrm{O}_{3}$ vs. Mg\# in clinopyroxenes of the basalts from the South Andaman Island ophiolite. Low-pressure clinopyroxene field is from 1 atm experimental studies of N-MORB (Elthon, 1987). 
massive basalts of the present study plot within the fields of tholeiitictype volcanic arc basalts on the $\mathrm{Ti}$ vs. $(\mathrm{Ca}+\mathrm{Na}),(\mathrm{Ti}+\mathrm{Cr}) \mathrm{vs}$. $\mathrm{Ca}$ and $\mathrm{Al}$ vs. Ti covariation diagrams of Leterrier et al. (1982) (Fig. 6a-c). Fig. 6d highlights that clinopyroxenes of the studied basalts originated at low pressures as demonstrated by 1 atmosphere experimental studies of N-type MORB (Elthon, 1987).

Two kinds of thermobarometers finds use to calculate the equilibrium pressure $(\mathrm{P})$ and temperature $(\mathrm{T})$ of clinopyroxene crystallization. The first approach is based on the $\mathrm{P}-\mathrm{T}$ sensitive chemical equilibrium (i.e., T-dependent jadeite-diopside/hedenbergite exchange equilibrium and $\mathrm{P}$ dependent jadeite-melt equilibrium) between clinopyroxene and host melt (clinopyroxene-melt thermobarometer; Putirka et al., 1996, 2003; Putirka, 2008). The other approach is based on the clinopyroxene components only (single-clinopyroxene thermobarometer; Nimis, 1995, 1999; Nimis and Taylor, 2000; Putirka, 2008) (Sun et al., 2020).

Temperature (T) and pressures (P) of clinopyroxene crystallization in massive basalts from South Andaman Island Ophiolite have been estimated using Putirka (2008b) clinopyroxene-only thermometer (Eq. $32 \mathrm{~d}, \mathrm{R}^{2} 0.36, \mathrm{SEE} \pm 87^{\circ} \mathrm{C}$ for hydrous) and barometer (Eq. 32b, $\mathrm{R}^{2}$ $0.91, \mathrm{SEE} \pm 2.6 \mathrm{kbar})$. This barometer and thermometer are recalibrated from Nimis (1995) and Nimis and Taylor (2000), respectively and are more precise than their original formulations with reduced systematic errors.

The calculated P-T results for our samples are shown in Fig. 7. Due to the absence of glass in our samples, we assume the whole-rock composition as representative of the original liquid in equilibrium with phenocrysts. These clinopyroxene phenocryst show low crystallization pressures of 3-8 kbar, corresponding to a depth (d) range of 15-29 km, using the expression $\mathrm{d}(\mathrm{km})=3.02 \times \mathrm{P}(\mathrm{kbar})+5$ (Scarrow and Cox, 1995). The estimated average temperature of clinopyroxene crystallization is $1201^{\circ} \mathrm{C}$ with a maximum-minimum range of $1223-1168^{\circ} \mathrm{C}$ (Table S3).

\section{Spinel}

A minor amount of subhedral chromian spinel is observed in two of the massive basalt samples AN 2/5 and AN 2/6 (Table S4). The spinels have a composition range of $\mathrm{TiO}_{2}=0.57-0.88$ wt. $\%, \mathrm{Al}_{2} \mathrm{O}_{3}=18.92-$ 24.97 wt. $\%, \mathrm{MgO}=11.04-12.41$ wt. $\%$ and $\mathrm{Cr} \#=0.51-0.60$ (Table $\mathrm{S} 3$ ). The spinel $\mathrm{Cr} \#$ vs. $\mathrm{TiO}_{2}$ (wt.\%) relationship has compositions that plot within the MORB field (Fig. 8a-b).

\section{Fe-oxides}

The oxide phase belonging to the $\mathrm{FeO}-\mathrm{Fe}_{2} \mathrm{O}_{3}-\mathrm{TiO}_{2}$ system is represented by magnetite in both pillow and massive basalt. $\mathrm{TiO}_{2}$ content in the magnetite varies from 0.45 to $2.44 \mathrm{wt} . \%$ and $\mathrm{FeO}$ range from 69.05-83.58 wt.\% (Table S5). Analysed magnetite is close to a magnetite-ulvo-spinel solid solution with $<\sim 0.1(\mathrm{Cr}+\mathrm{A} 1+\mathrm{Mg}+\mathrm{Mn})$ per 4 oxygen atoms.

\section{Amphibole}

Amphiboles occur primarily as anhedral crystals associated with chlorite-augite contacts or as randomly oriented bundles in chlorite. Supplementary Table S6 shows the chemical compositions of representative amphiboles. Most amphiboles classify as magnesio-hornblende in the studied basalts (Leake et al., 1997) in massive and pillow basalt (Fig. 8c) with $\mathrm{Ca}>1.50,(\mathrm{Na}+\mathrm{K})<0.5$, Si range between 6.5 to 7.5 , and $\left[\mathrm{Mg} /\left(\mathrm{Mg}+\mathrm{Fe}^{2+}\right)\right]>0.5$ (Table S5). However, few compositions of edenite and ferroedenite are present in pillow basalt.

\section{Titanite}

Titanite is present in both massive and pillow basalt. As a result of basalt undergoing mild metamorphism, the ilmenite has converted

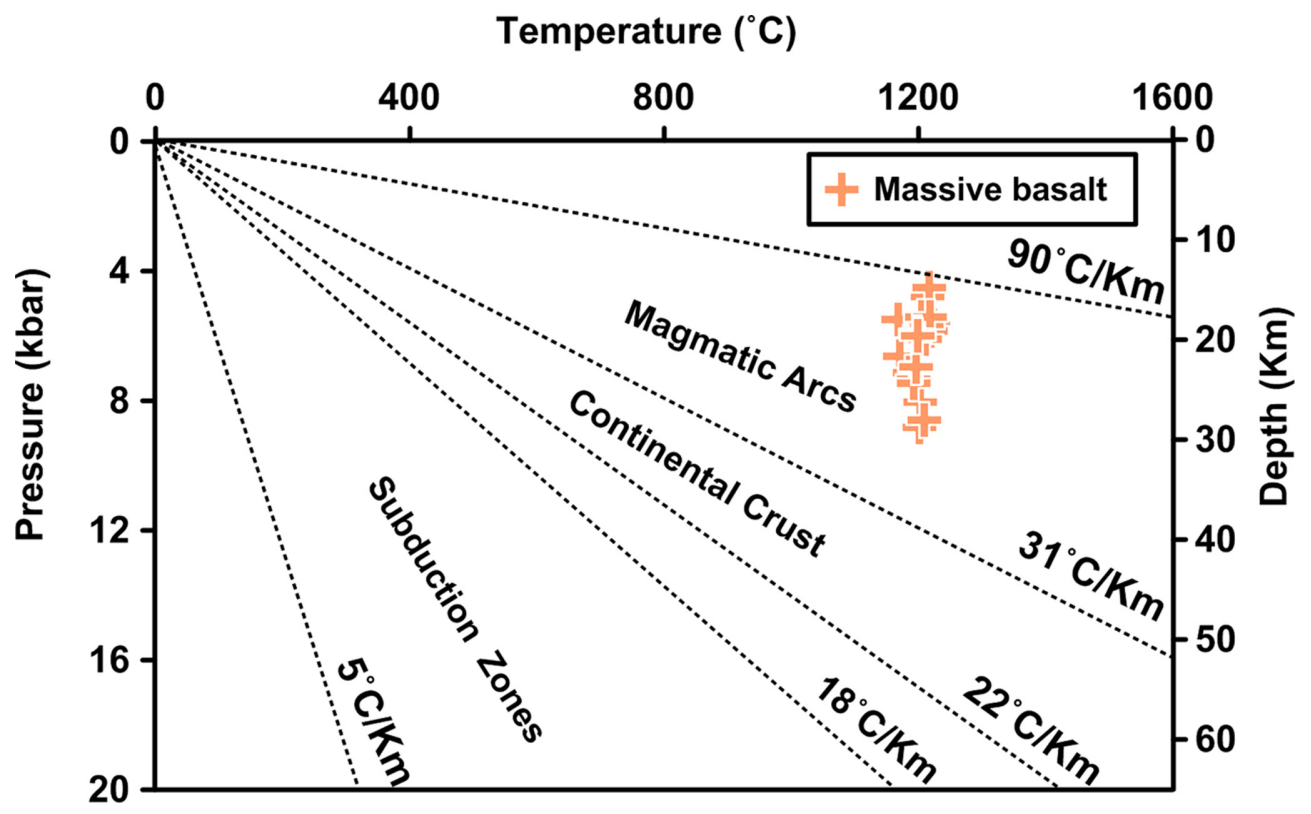

Figure 7. A plot of temperature $\left({ }^{\circ} \mathrm{C}\right)$, pressure (kbar) and depth (km) estimated for basalt samples of South Andaman Ophiolite using clinopyroxeneonly thermo-barometer of Putirka (2008b). Simple linear temperature-depth trends for subduction, continental crust and magmatic arc environments are from Spear (1993). 

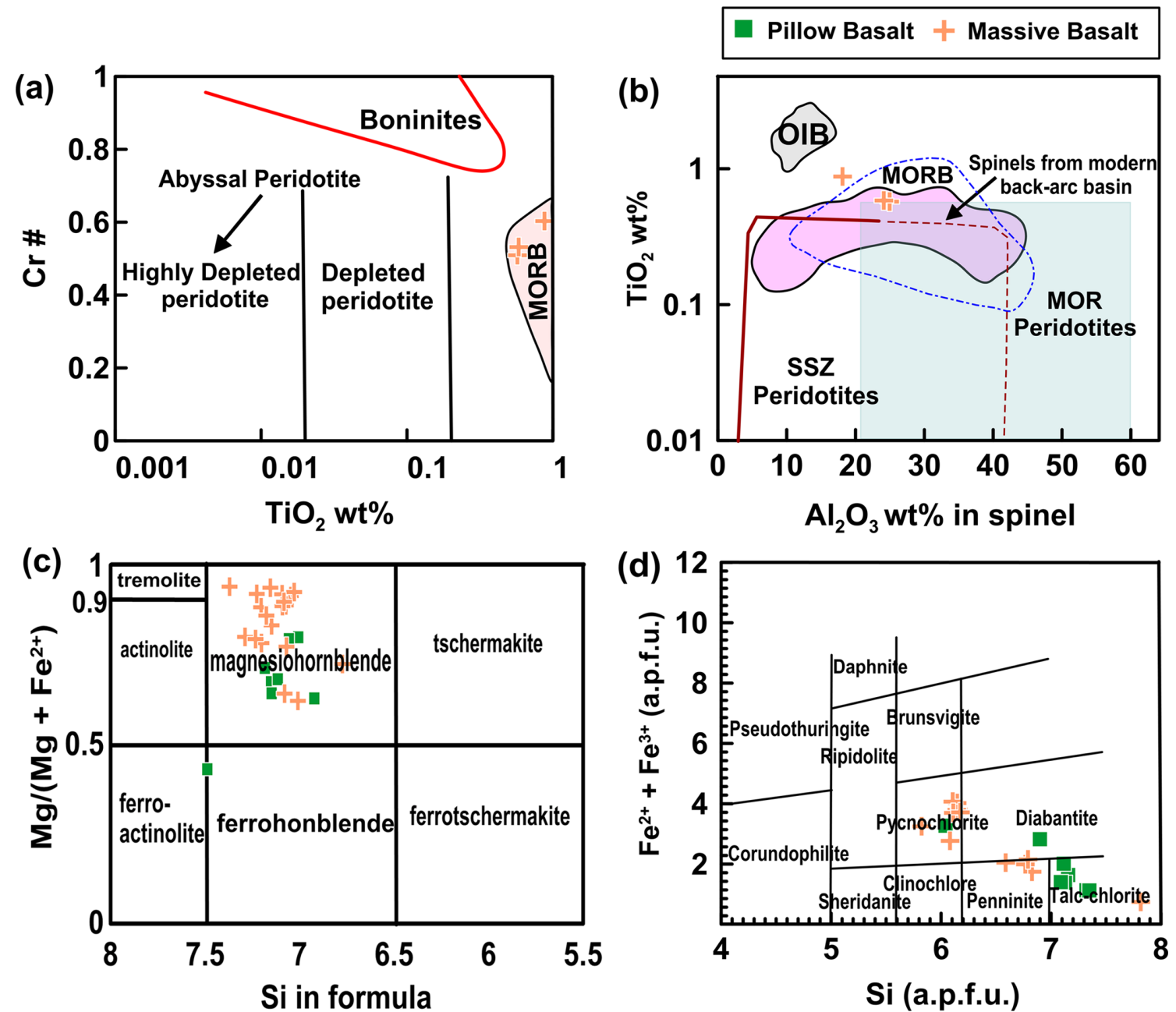

Figure 8. (a) $\mathrm{TiO}_{2}$ vs. Cr\# diagram in spinels of basalts of South Andaman Island ophiolite. Fields are after Dick and Bullen (1984); Jan and Windley (1990); Arai (1992). (b) $\mathrm{TiO}_{2}$ vs. $\mathrm{Al}_{2} \mathrm{O}_{3}$ of spinels from basalts of the South Andaman Island Ophiolite. Fields are after Kamenetsky et al., (2001). (c) Nomenclature of amphiboles from the basalts of the South Andaman Island Ophiolite (after Leake et al., 1997). (d) Nomenclature of chlorite of Basalts of South Andaman Ophiolite (after Hey, 1954).

into titanite. The analyzed titanite is close to $\mathrm{CaTiSiO}_{5}($ Table S7).

\section{Chlorites}

Chlorites exhibit an average $\mathrm{Fe}$ and $\mathrm{Mg}$ value of 2.50 and 3.54 a.p.f.u respectively, and their $\mathrm{Fe} /(\mathrm{Fe}+\mathrm{Mg})$ ratios vary between 0.24 to 0.81. The compositions of these chlorite phases plot in the fields of pycnochlorite, diabantite, penninite and talc-chlorite (Fig. 8d). Si values in these chlorites vary from 6.08 to 6.89 a.p.f.u. Ti content varies from 0 to 0.05 a.p.f.u. in the analyzed chlorites and calcium, potassium and sodium are present as minor impurities in the chlorites which are known to occur occasionally as interlayer cations in chlorites. Compositions of chlorites from the studied samples are in Table S8.

\section{Carbonates}

Carbonates fill the amygdales and occur as irregular aggregates in massive basalt. All analyzed carbonates are similar in composition to $\mathrm{CaCO}_{3}$ (Table S9).

\section{Epidotes}

In massive basalts, epidote fills amygdales, occurs as small grains enclosed by chlorite. At places, it partially replaces calcic plagioclase as well. Table S10 presents the compositional data for epidote from the South Andaman Island ophiolite. Data show that the examined epidotes exhibit $\mathrm{Al}$ values ranging from 2.01-2.30 a.p.f.u.

\section{Geochemistry}

Whole rock major oxide and trace element data and a selection of inter-element ratios of seventeen samples from the South Andaman Island pillow and massive basalts are presented in Table 1 and the geochemical characteristics of their lavas are described below.

\section{Major and trace element chemistry}

The major element composition conforms to the compositional range of basalts with $\mathrm{SiO}_{2}$ contents of 44.43-51.91 wt.\% for the pillow basalts and $42.81-49.28$ wt. $\%$ for the massive variety. The samples 


\begin{tabular}{|c|c|c|c|c|c|c|c|c|c|c|c|c|c|c|c|c|c|}
\hline Sample no & ANA7/1 & ANA7/2 & ANA7/7 & ANA7/8 & ANA9/1 & AN2/7 & AN2/8 & $\overline{\mathrm{AN} 13 / 26}$ & AN15/28 & $\overline{\text { AN } 14 / 27}$ & AN 2/10 & A AN 2/6 & $\overline{\mathrm{AN} 2 / 12}$ & AN 19/4 & $\overline{\text { AN } 12 / 25}$ & $=7$ AN 2/4 & $\overline{\mathrm{AN} 2 / 5}$ \\
\hline Basalt variety & Pillow & Pillow & Pillow & Pillow & Pillow & Massive & Massive & Massive & Massive & Massive & Massive & Massive & Massive & Massive & Massive & Massive & Massive \\
\hline \multicolumn{18}{|c|}{ Major oxide (wt.\%) } \\
\hline $\mathrm{SiO}_{2}$ & 47.82 & 44.43 & 47.3 & 46.54 & 45.24 & 48.57 & 48.5 & 48.27 & 49.17 & 48.45 & 42.81 & 44.44 & 47.87 & 49.28 & 48.13 & 48.08 & 45.35 \\
\hline $\mathrm{TiO}_{2}$ & 1.65 & 0.77 & 1.21 & 1.34 & 1.24 & 1.34 & 1.37 & 1.52 & 1.06 & 1.57 & 1.27 & 1.24 & 1.24 & 1.54 & 1.53 & 1.15 & 1.24 \\
\hline $\mathrm{Al}_{2} \mathrm{O}_{3}$ & 15.73 & 10.55 & 15.5 & 14.02 & 11.56 & 12.59 & 12.27 & 15.52 & 13.26 & 16.93 & 13.45 & 12.67 & 13.85 & 12.68 & 14.04 & 15.35 & 13.03 \\
\hline $\mathrm{MgO}$ & 4.03 & 5.38 & 6.93 & 3.62 & 5.25 & 5.58 & 6.33 & 5.12 & 6.32 & 3.8 & 7.94 & 6.96 & 7.56 & 8.49 & 8.55 & 5.62 & 6.15 \\
\hline $\mathrm{Na}_{2} \mathrm{O}$ & 4 & 2.83 & 3.63 & 3.86 & 0.51 & 3.52 & 3.53 & 3.53 & 2.67 & 3.96 & 1.84 & 3.26 & 3.68 & 3.73 & 3.05 & 3.84 & 3.53 \\
\hline $\mathrm{P}_{2} \mathrm{O}_{5}$ & 0.95 & 0.08 & 0.12 & 0.16 & 0.09 & 0.14 & 0.11 & 0.14 & 0.1 & 0.2 & 0.12 & 0.12 & 0.11 & 0.12 & 0.12 & 0.12 & 0.12 \\
\hline $\mathrm{K}_{2} \mathrm{O}$ & 1.26 & 0.17 & 0.47 & 0.6 & 0.01 & 0.57 & 0.12 & 1 & 1.29 & 1.2 & 0.03 & 0.04 & 0.02 & 0.13 & 0.48 & 0.77 & 0.04 \\
\hline $\mathrm{CaO}$ & 8.62 & 19.01 & 10.29 & 12.02 & 19.05 & 12.68 & 11.79 & 8.89 & 12.22 & 7.02 & 14.52 & 15.13 & 11.32 & 9.99 & 10.59 & 10.1 & 13.9 \\
\hline $\mathrm{MnO}$ & 0.15 & 0.1 & 0.15 & 0.17 & 0.12 & 0.2 & 0.21 & 0.24 & 0.16 & 0.15 & 0.15 & 0.16 & 0.14 & 0.17 & 0.17 & 0.17 & 0.18 \\
\hline $\mathrm{Fe}_{2} \mathrm{O}_{3}$ & 10.71 & 7.88 & 10.39 & 11.83 & 10.06 & 11.5 & 11.76 & 12.57 & 9.73 & 14.04 & 10.75 & 10.28 & 10.92 & 9.8 & 10.52 & 11.27 & 10.69 \\
\hline Total & 94.92 & 91.2 & 95.99 & 94.16 & 93.13 & 96.69 & 95.99 & 96.8 & 95.98 & 97.32 & 92.88 & 94.3 & 96.71 & 95.93 & 97.18 & 96.47 & 94.23 \\
\hline LOI & 5.37 & 9.73 & 4.26 & 6.77 & 7.85 & 5.06 & 5.17 & 4.21 & 5.26 & 4.33 & 7.99 & 6.26 & 4.76 & 4.61 & 3.64 & 4.89 & 5.26 \\
\hline \multicolumn{18}{|c|}{ Trace elements (ppm) } \\
\hline $\mathrm{Ba}$ & 204 & 37 & 56 & 40 & 17 & 48 & 48 & 87 & 48 & 70 & 30 & 15 & 34 & 55 & 59 & 62 & 37 \\
\hline $\mathrm{Cr}$ & 233 & 428 & 455 & 435 & 288 & 353 & 428 & 399 & 451 & 559 & 363 & 386 & 601 & 381 & 310 & 641 & 407 \\
\hline V & 198 & 254 & 305 & 280 & 294 & 313 & 313 & 334 & 269 & 268 & 241 & 274 & 251 & 287 & 291 & 241 & 274 \\
\hline $\mathrm{Sc}$ & 44 & 39 & 42 & 49 & 41 & 44 & 43 & 45 & 38 & 51 & 41 & 45 & 42 & 41 & 39 & 44 & 43 \\
\hline Co & 44 & 33 & 43 & 43 & 34 & 48 & 48 & 54 & 40 & 43 & 45 & 44 & 52 & 41 & 48 & 61 & 49 \\
\hline $\mathrm{Ni}$ & 121 & 85 & 139 & 131 & 108 & 101 & 130 & 100 & 104 & 74 & 105 & 127 & 155 & 150 & 135 & 113 & 107 \\
\hline $\mathrm{Cu}$ & 22 & 34 & 31 & 28 & 59 & 28 & 98 & 134 & 54 & 64 & 19 & 91 & 82 & 63 & 66 & 84 & 44 \\
\hline $\mathrm{Zn}$ & 117 & 59 & 82 & 95 & 66 & 101 & 88 & 187 & 69 & 146 & 83 & 79 & 131 & 76 & 83 & 130 & 88 \\
\hline $\mathrm{Ga}$ & 16.91 & 14.49 & 15.48 & 16.31 & 21.56 & 15.23 & 17.48 & 21.06 & 14.99 & 19.79 & 12.86 & 16.1 & 18.4 & 12.35 & 15.6 & 15.92 & 18.86 \\
\hline $\mathrm{Pb}$ & 32.4 & 11.2 & 5 & 21.8 & 3.9 & 13.7 & 8.2 & 22 & 4.4 & 23.4 & 1.5 & 9.1 & 14.2 & BDL & BDL & 24 & 13.6 \\
\hline Th & 1 & 0.1 & 0.4 & 0.3 & 0.2 & BDL & BDL & BDL & BDL & BDL & BDL & 0.84 & BDL & BDL & 1.27 & 1.73 & 0.62 \\
\hline $\mathrm{Rb}$ & 27 & 3 & 8 & 13 & BDL & 11 & 1 & 21 & 23 & 36 & BDL & 1 & BDL & 1 & 8 & 19 & BDL \\
\hline $\mathrm{U}$ & 0.9 & 0.4 & 0.6 & 0.7 & 0.5 & BDL & BDL & BDL & BDL & BDL & BDL & BDL & BDL & BDL & BDL & BDL & BDL \\
\hline $\mathrm{Sr}$ & 340 & 81 & 307 & 187 & 20 & 187 & 79 & 307 & 194 & 262 & 52 & 85 & 41 & 152 & 200 & 201 & 74 \\
\hline Y & 36 & 18 & 24 & 33 & 24 & 28 & 29 & 36 & 24 & 41 & 25 & 26 & 23 & 27 & 30 & 27 & 26 \\
\hline $\mathrm{Zr}$ & 126 & 39 & 71 & 80 & 78 & 76 & 82 & 90 & 59 & 87 & 81 & 76 & 71 & 97 & 94 & 71 & 75 \\
\hline $\mathrm{Nb}$ & 10 & 1.5 & 2.8 & 2.7 & 2.3 & 3.2 & 3 & 3.2 & 2.9 & 3.5 & 4.3 & 2.9 & 3.3 & 3.2 & 3.3 & 3.3 & 3.2 \\
\hline
\end{tabular}


Table 1. Continued

\begin{tabular}{|c|c|c|c|c|c|c|c|c|c|c|c|c|c|c|c|c|c|}
\hline "Sample no & ANA7/1 & ANA7/2 & ANA7/7 & ANA7/8 & ANA9/1 & $\begin{array}{l}\text { AN2/7 } \\
\end{array}$ & $\overline{\text { AN2/8 }}$ & $\overline{\mathrm{AN} 13 / 26}$ & AN15/28 & AN 14/27 & AN 2/10 & AN 2/6 & AN 2/12 & AN 19/4 & AN 12/25 & $\overline{~ A N ~ 2 / 4 ~}$ & AN 2/5 \\
\hline Basalt variety & Pillow & Pillow & Pillow & Pillow & Pillow & Massive & Massive & Massive & Massive & Massive & Massive & Massive & Massive & Massive & Massive & Massive & Massive \\
\hline \multicolumn{18}{|l|}{ REE (ppm) } \\
\hline $\mathrm{La}$ & 10.84 & 3.47 & 3.16 & 2.52 & 3.23 & 3.5 & 3.2 & 3.5 & 2.8 & 2.75 & 3.35 & 2.35 & 3.573 & 4.204 & 3.37 & 6.92 & 3.01 \\
\hline $\mathrm{Ce}$ & 18.75 & 5.06 & 8.3 & 8.13 & 8.25 & 9.7 & 9.2 & 10.3 & 7.5 & 6.15 & 9.1 & 6.63 & 8.817 & 11.881 & 9.8 & 7.97 & 8.46 \\
\hline $\operatorname{Pr}$ & 3.22 & 1.29 & 1.43 & 1.23 & 1.57 & 1.8 & 1.7 & 1.8 & 1.4 & 1.09 & 1.59 & 1.14 & 1.5 & 2.177 & 1.769 & 2.06 & 1.54 \\
\hline $\mathrm{Nd}$ & 14.38 & 6.08 & 6.92 & 6.47 & 7.76 & 8.9 & 8.3 & 9.1 & 7.2 & 5.62 & 7.99 & 5.96 & 7.603 & 11.292 & 9.166 & 9.78 & 8.08 \\
\hline $\mathrm{Sm}$ & 3.9 & 2.13 & 2.4 & 2.26 & 2.67 & 3.04 & 2.94 & 3.19 & 2.51 & 1.93 & 2.81 & 2 & 2.582 & 4.110 & 3.29 & 2.87 & 2.82 \\
\hline $\mathrm{Eu}$ & 1.52 & 0.8 & 0.89 & 0.85 & 0.98 & 1.12 & 1.06 & 1.18 & 0.96 & 0.69 & 1 & 0.74 & 0.95 & 1.389 & 1.135 & 1.02 & 1.01 \\
\hline $\mathrm{Gd}$ & 4.85 & 2.86 & 3.09 & 3.02 & 3.44 & 4.04 & 3.76 & 4.11 & 3.27 & 2.47 & 3.68 & 2.81 & 3.396 & 5.416 & 4.297 & 3.65 & 3.83 \\
\hline $\mathrm{Tb}$ & 0.86 & 0.55 & 0.59 & 0.58 & 0.66 & 0.78 & 0.73 & 0.8 & 0.63 & 0.48 & 0.72 & 0.52 & 0.65 & 1.078 & 0.834 & 0.67 & 0.74 \\
\hline Dy & 5.51 & 3.72 & 4.04 & 3.94 & 4.41 & 5.22 & 4.88 & 5.37 & 4.24 & 3.29 & 4.71 & 3.58 & 4.458 & 7.344 & 5.761 & 4.33 & 4.95 \\
\hline Но & 1.25 & 0.83 & 0.9 & 0.92 & 1.01 & 1.18 & 1.1 & 1.22 & 0.94 & 0.73 & 1.05 & 0.81 & 1.014 & 1.657 & 1.291 & 0.94 & 1.11 \\
\hline $\mathrm{Er}$ & 3.33 & 2.21 & 2.36 & 2.46 & 2.61 & 3.19 & 3.01 & 3.31 & 2.56 & 2.01 & 2.9 & 2.27 & 2.683 & 4.437 & 3.486 & 2.54 & 3.16 \\
\hline $\mathrm{Tm}$ & 0.51 & 0.35 & 0.37 & 0.37 & 0.41 & 0.5 & 0.47 & 0.52 & 0.39 & 0.3 & 0.45 & 0.35 & 0.43 & 0.694 & 0.553 & 0.37 & 0.49 \\
\hline $\mathrm{Yb}$ & 3.43 & 2.37 & 2.51 & 2.51 & 2.78 & 3.31 & 3.07 & 3.37 & 2.61 & 1.95 & 2.92 & 2.24 & 2.74 & 4.352 & 3.538 & 2.42 & 3.17 \\
\hline $\mathrm{Lu}$ & 0.54 & 0.35 & 0.38 & 0.41 & 0.41 & 0.51 & 0.48 & 0.53 & 0.4 & 0.3 & 0.45 & 0.36 & 0.437 & 0.687 & 0.555 & 0.38 & 0.5 \\
\hline $\mathrm{Mg} \#$ & 42.70 & 57.49 & 56.91 & 37.73 & 50.82 & 49.00 & 51.60 & 44.65 & 56.26 & 34.90 & 59.40 & 57.28 & 57.82 & 63.18 & 61.68 & 49.69 & 53.26 \\
\hline $\mathrm{Sr} / \mathrm{Rb}$ & 12.59 & 27.00 & 38.38 & 14.38 & & 17.00 & 79.00 & 14.62 & 8.43 & 7.28 & & 85.00 & & 152.00 & 25.00 & 10.58 & \\
\hline $\mathrm{K} / \mathrm{Ba}$ & 51.27 & 38.14 & 69.67 & 124.52 & 4.88 & 98.57 & 20.75 & 95.41 & 223.09 & 142.30 & 8.30 & 22.14 & 4.88 & 19.62 & 67.53 & 103.09 & 8.97 \\
\hline $\mathrm{K} / \mathrm{Rb}$ & 387.38 & 470.39 & 487.68 & 383.12 & & 430.14 & 996.12 & 395.29 & 465.58 & 276.70 & & 332.04 & & 1079.13 & 498.06 & 336.41 & \\
\hline $\mathrm{Zr} / \mathrm{Ti}$ & 0.01 & 0.01 & 0.01 & 0.01 & 0.01 & 0.01 & 0.01 & 0.01 & 0.01 & 0.01 & 0.01 & 0.01 & 0.01 & 0.01 & 0.01 & 0.01 & 0.01 \\
\hline $\mathrm{Nb} / \mathrm{Y}$ & 0.28 & 0.08 & 0.12 & 0.08 & 0.10 & 0.11 & 0.10 & 0.09 & 0.12 & 0.09 & 0.17 & 0.11 & 0.14 & 0.12 & 0.11 & 0.12 & 0.12 \\
\hline $\mathrm{Zr} / \mathrm{Y}$ & 3.50 & 2.17 & 2.96 & 2.42 & 3.25 & 2.71 & 2.83 & 2.50 & 2.46 & 2.12 & 3.24 & 2.92 & 3.09 & 3.59 & 3.13 & 2.63 & 2.88 \\
\hline $\mathrm{Ti} / \mathrm{V}$ & 49.96 & 18.17 & 23.78 & 28.69 & 25.29 & 25.67 & 26.24 & 27.28 & 23.62 & 35.12 & 31.59 & 27.13 & 29.62 & 32.17 & 31.52 & 28.61 & 27.13 \\
\hline $\mathrm{Nb} / \mathrm{Zr}$ & 0.08 & 0.04 & 0.04 & 0.03 & 0.03 & 0.04 & 0.04 & 0.04 & 0.05 & 0.04 & 0.05 & 0.04 & 0.05 & 0.03 & 0.04 & 0.05 & 0.04 \\
\hline $\mathrm{Nb} / \mathrm{La}$ & 0.92 & 0.43 & 0.89 & 1.07 & 0.71 & 0.91 & 0.94 & 0.91 & 1.04 & 1.27 & 1.28 & 1.23 & 0.92 & 0.76 & 0.98 & 0.48 & 1.06 \\
\hline $\mathrm{Sr} / \mathrm{Y}$ & 9.44 & 4.50 & 12.79 & 5.67 & 0.83 & 6.68 & 2.72 & 8.53 & 8.08 & 6.39 & 2.08 & 3.27 & 1.78 & 5.63 & 6.67 & 7.44 & 2.85 \\
\hline $\mathrm{Sr} / \mathrm{Sr}^{*}$ & 1.45 & 0.84 & 2.83 & 1.92 & 0.17 & 1.36 & 0.61 & 2.20 & 1.77 & 3.07 & 0.42 & 0.95 & 0.35 & 0.89 & 1.44 & 1.30 & 0.61 \\
\hline $\mathrm{Ti} / \mathrm{Ti}^{*}$ & 0.92 & 0.72 & 1.04 & 1.19 & 0.95 & 0.89 & 0.95 & 0.97 & 0.86 & 1.66 & 0.91 & 1.24 & 0.98 & 0.75 & 0.94 & 0.85 & 0.87 \\
\hline $\mathrm{Eu} / \mathrm{Eu}^{*}$ & 1.07 & 0.99 & 1.00 & 0.99 & 0.99 & 0.98 & 0.97 & 1.00 & 1.02 & 0.97 & 0.95 & 0.95 & 0.98 & 0.90 & 0.92 & 0.96 & 0.94 \\
\hline$(\mathrm{La} / \mathrm{Sm})_{\mathrm{N}}$ & 1.79 & 1.05 & 0.85 & 0.72 & 0.78 & 0.74 & 0.70 & 0.71 & 0.72 & 0.92 & 0.77 & 0.76 & 0.89 & 0.66 & 0.66 & 1.56 & 0.69 \\
\hline$(\mathrm{Gd} / \mathrm{Yb})_{\mathrm{N}}$ & 1.17 & 1.00 & 1.02 & 1.00 & 1.02 & 1.01 & 1.01 & 1.01 & 1.04 & 1.05 & 1.04 & 1.04 & 1.03 & 1.03 & 1.00 & 1.25 & 1.00 \\
\hline$(\mathrm{La} / \mathrm{Yb})_{\mathrm{N}}$ & 2.27 & 1.05 & 0.90 & 0.72 & 0.83 & 0.76 & 0.75 & 0.74 & 0.77 & 1.01 & 0.82 & 0.75 & 0.94 & 0.69 & 0.68 & 2.05 & 0.68 \\
\hline$(\mathrm{Sm} / \mathrm{Yb})_{\mathrm{N}}$ & 1.26 & 1.00 & 1.06 & 1.00 & 1.07 & 1.02 & 1.06 & 1.05 & 1.07 & 1.10 & 1.07 & 0.99 & 1.05 & 1.05 & 1.03 & 1.32 & 0.99 \\
\hline
\end{tabular}


are characterized by relatively low $\mathrm{MgO}$ contents (3.62-8.14 wt.\% for pillow basalts; $3.8-8.55 \mathrm{wt} . \%$ for massive basalts) with a combined $\mathrm{Mg}$ \# varying from 35 to 63 . The samples have a total alkali $\left(\mathrm{Na}_{2} \mathrm{O}+\right.$ $\mathrm{K}_{2} \mathrm{O}$ ) content which ranges from 1.87 to $5.61 \mathrm{wt} . \%$ in massive basalt while in pillows it varies from $0.56-5.26 \mathrm{wt} . \%$, with an average $\mathrm{Na}_{2} \mathrm{O}$ / $\mathrm{K}_{2} \mathrm{O}$ ratio of 16.99 and 41.63 for the pillow and massive basalt respectively, hence are relatively sodium rich. The very high $\mathrm{Na}_{2} \mathrm{O} / \mathrm{K}_{2} \mathrm{O}$ ratio could be the result of seafloor alteration process (Bonev and Stampfli, 2008). These extrusives exhibit sub-alkaline characteristics and are tholeiitic. All samples fall within the low- to medium - K compositional fields. The aluminium saturation index values of these extrusives range from 0.48 to 1.13 .

In the $\mathrm{Zr} / \mathrm{TiO}_{2}$ vs. $\mathrm{Nb} / \mathrm{Y}$ compositional discrimination diagram of Winchester and Floyd (1977), all samples plot in the basalt field (Supplementary Fig. S1). The fluid mobile large ion lithophile elements (LILEs) are compositionally variable for the basalt samples (K: 8310459 ppm, Rb: 1-36 ppm, Sr: 20-340 ppm, Ba: 17-204 and U: 0.5$0.9 \mathrm{ppm})$. The LILE ratios are high, e.g., K/Rb (276-1079) and Sr/Rb (10-152) (Table 1). The plots of bivariate diagrams of selected major elements $\left(\mathrm{SiO}_{2}\right.$ and $\left.\mathrm{K}_{2} \mathrm{O}\right)$ and fluid mobile elements (Ba, $\left.\mathrm{Sr}\right)$ do not display systematic correlations with $\mathrm{Zr}$ contents (Supplementary Fig. S2). The fluid immobile elements also display a moderate variations for both basalt types (Ti: 6355-9892 ppm, V: 241-334 ppm, Th: 0.21.73 ppm, Yb: 1.95-3.43 ppm, Nb: 1.5-10 ppm, Zr: 71-126 ppm, Y: 24-41 ppm, La: 2.52-10.84 ppm, and Sm: 2.00-4.11 ppm). The ratios of fluid immobile elements are consistent with compositional range of tholeiite basalts (for example $\mathrm{Zr} / \mathrm{Ti}=0.01, \mathrm{Nb} / \mathrm{Y}=0.09-0.28, \mathrm{Ti} / \mathrm{V}=$ $18.97-49.96$ and $\left.(\mathrm{La} / \mathrm{Sm})_{\mathrm{N}}=0.66-1.79\right)$. Also, in the binary plot of $\mathrm{La}$ vs. Yb (Ross and Bédard, 2009), the magma of the studied basalts is tholeiitic (Fig. S3). Selected fluid immobile elements $\left(\mathrm{TiO}_{2}, \mathrm{Sm}, \mathrm{Nb}\right.$, Gd) display systematic correlations with $\mathrm{Zr}$ contents (See Fig. S2). The basaltic rocks are sub-alkaline as the ratio of fluid immobile elements such as $\mathrm{Zr} / \mathrm{Y}(2.12-3.59), \mathrm{La} / \mathrm{Nb}(0.78-2.31)$ and $\mathrm{Nb} / \mathrm{Y}(0.08-$ 0.28) are low (Winchester and Floyd, 1977) (Table 1).
Rare earth element (REE) patterns of massive and pillow basalts normalized to chondrite values after Sun and McDonough, 1989 are presented in Fig. 9a. The studied basalts exhibit slight depletion of light REE (LREE) relative to the middle REE (MREE) as observed from $(\mathrm{La} / \mathrm{Sm})_{\mathrm{N}}$ values, which range from 0.66 to $1.56($ average $=0.81)$ for massive lavas and 0.72 to 1.79 (average $=1.03$ ) for pillow lavas. The $(\mathrm{Gd} / \mathrm{Yb})_{\mathrm{N}}$ ratios vary between 0.99 to 1.24 (average $\left.=1.04\right)$ for massive basalts and between 0.99-1.17 (average $=1.041$ ) for pillow basalt, indicating a flat MREE to heavy REE (HREE) trend normalized to the chondrite values. These features are characteristic of normal mid-ocean ridge (N-MOR) type of basaltic rocks. The unfractionated patterns of HREE indicate that the magma source belongs to the spinel stability field of the mantle. The Eu anomaly $\left(\mathrm{Eu} / \mathrm{Eu}^{*}\right)$ has been calculated using the formulation of Taylor and McLennan (1985) [Eu/ $\left.\mathrm{Eu}^{*}=\mathrm{Eu}_{\mathrm{N}} /\left(\mathrm{Sm}_{\mathrm{N}} \times \mathrm{Gd}_{\mathrm{N}}\right) 1 / 2\right]$. The Eu anomaly in massive and pillow basaltic rocks vary between $0.90-1.02$ (average $=0.96$ ) and 0.98-1.06 (average $=1.00$ ), respectively, thus representing very weak negative or no Eu anomaly with a variable $\mathrm{Sr}$ anomaly for the studied samples. The weak to no Eu anomaly with variable Sr anomaly are found inconsistent to each other, which probably indicate that plagioclase fractionation did not play a major role during the process of magma evolution (Floyd et al., 1991; Slovenec et al., 2010; Qian et al., 2016). The low $\mathrm{Nb} / \mathrm{La}$ ratios (0.43-1.28), selective LILE enrichment (Ba, $\mathrm{Rb}, \mathrm{Sr}, \mathrm{K}$ ) and high field strength element (HFSE) depletion (Nb, Ti, $\mathrm{Zr}$ ) in the south Andaman basalts suggest their affinity to volcanic arcs (Saunders and Tarney, 1979; Caulfield et al., 2008; Ozdamar, 2016).

On the primitive mantle normalized multi-element spider diagram, the basaltic massive and pillow rocks of the south Andaman island show depletion in HFSEs (e.g., Nb and Ti) and enrichment in LILEs (e.g., Rb, Ba, K, Th), which are typical of subduction signatures (Fig. 9b). Besides, few samples show variable $\mathrm{K}$ and $\mathrm{Sr}$ enrichment which is probably due to their relative mobilities during post-magmatic processes (Zhang et al., 2008).

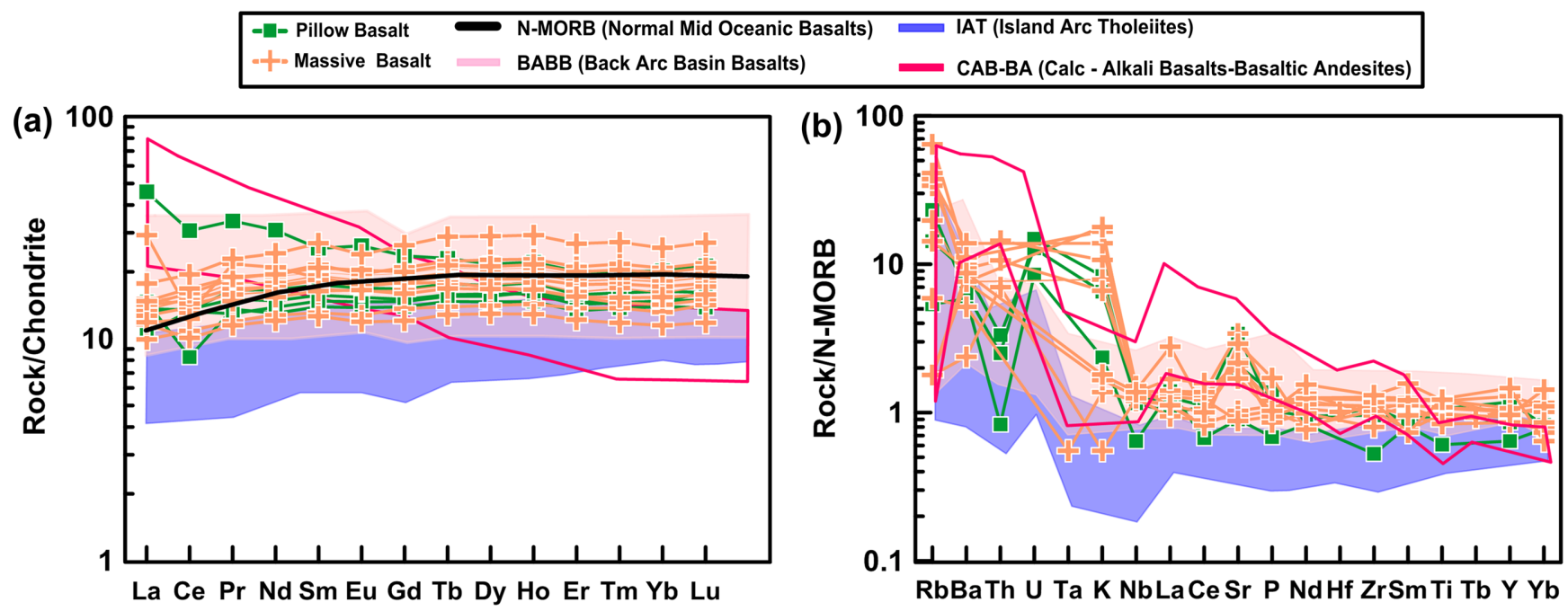

Figure 9. (a) Chondrite-normalized REE patterns (b) N-MORB normalized incompatible element patterns for massive and pillow lavas of the South Andaman Island ophiolites. The compositions of island-arc tholeiites (IAT), calc-alkaline basalts and basaltic andesites (CAB-BA), and back-arc basin basalts (BABB) from various ophiolitic complexes and modern oceanic settings, as well as modern normal-type mid-ocean ridge basalt ( $N$ MORB), are shown for comparison along with the data. Data source, IAT: Ewart et al., (1994); Yuan et al., (2005); Saccani et al., (2008a); CAB-BA: Ewart et al., (1994); Saccani et al., (2008b); BABB: Ewart et al., (1994); Yuan et al., (2005); Saccani et al., (2008b); Rolland et al., (2009). Normalizing values and the compositions of N-MORB are from Sun and McDonough (1989). 


\section{Discussion}

\section{Petrogenesis}

\section{Alteration, crustal contamination and fractional crystal- lization}

Massive and pillow basalts of the South Andaman Island Ophiolite suite show variable degree of alteration as the loss on ignition (LOI) values range between $\sim 3.64$ and $9.73 \mathrm{wt} . \%$. Massive basalts also contain amygdales that are filled with calcite and chlorite minerals and which also contribute to the high LOI content of these rocks. The reason for high LOI values can be related either to seafloor hydrothermal alteration or to a post-kinematic process during emplacement of the ophiolitic slices. Under such circumstances, the mobility of trace elements varies selectively. LILEs such as $\mathrm{Ba}, \mathrm{Rb}, \mathrm{Sr}$ and $\mathrm{K}$ and many major oxides such as $\mathrm{K}_{2} \mathrm{O}, \mathrm{Na}_{2} \mathrm{O}, \mathrm{FeO}$ is commonly mobilized during alteration (e.g., Pearce and Norry, 1979) and their abundances in altered rocks are usually different than in fresh magmatic rocks (Humphris and Thompson, 1978). However, post-magmatic processes barely alter the REE and HFSE abundances in rocks and are therefore considered to be immobile during hydrothermal alteration (Winchester and Floyd, 1977; Humphris, 1984; Gardien et al., 2008; Ordóñez Calderón et al., 2008). Since the REEs and HFSEs show limited mobility in our samples, we use these elements for the tectono-magmatic interpretations of extrusives of the South Andaman Island Ophiolite suite.

The $\mathrm{La} / \mathrm{Nb}$ ratio in basalts does not change during fractional crystallization as wells as partial melting processes. But this ratio is known to increase when contaminated by continental crust, which is generally believed to be enriched in $\mathrm{La}$ and depleted in $\mathrm{Nb}$ (Rudnick and Gao, 2003). The $\mathrm{La} / \mathrm{Nb}$ ratio of the studied samples does not increase with increasing $\mathrm{SiO}_{2}$ contents, thus suggesting a minor role of crustal contamination in their evolution. Depleted LREE and almost flat MREE to HREE trends in the chondrite-normalized pattern of South Andaman Island basaltic rocks indicate their compositional similarity to normal mid-ocean ridge basalt (N-MORB).

$\mathrm{The} \mathrm{La} / \mathrm{Yb}$ vs. $\mathrm{Yb}$ and $\mathrm{Ce} / \mathrm{Yb}$ vs. $\mathrm{K}_{2} \mathrm{O}$ plots for our samples (Fig. 10 a-b) show a clear trend for fractional crystallization. This indicates that post melting, fractional crystallization has played a significant role in the evolution of these basalts.

\section{Tectonic setting and melt components}

The presence of negative $\mathrm{Nb}$ and $\mathrm{Ti}$ anomalies in studied basalts are suggestive of subduction influence. Also, the trend observed in $\mathrm{Zr} / \mathrm{Yb}$ vs. $\mathrm{Nb} / \mathrm{Yb}$ diagram for studied samples indicates their derivation of initial magma from the homogeneous MORB-like source, which was subsequently metasomatized and enriched by fluids derived from the subducting slab. The contamination of source by such fluids generally leads to the enhancement in melting at relatively low pressure without significantly enriching the source in LREE. This process may generate LREE-depleted melt or NMORB-type basalt in a subduction setting. The trends are shown in $\mathrm{Ba} / \mathrm{Th}$ vs. Th/Nb plot (Fig. 11a) indicate that the source of basalts understudy was influenced by both aqueous fluid and sediment melt additions. The pillow lavas show distinct subduction fluid addition, while the massive basalts have a clear indication of sediment melt addition.

Studies have shown that in a subduction system, shallow subduction input is characterized by elements that are mobile in low-temperature aqueous fluids, such as $\mathrm{Ba}, \mathrm{Rb}, \mathrm{Sr}$ and $\mathrm{Pb}$. However, deep subduction is marked by source enrichments in elements mobile in low-temperature aqueous fluids and also in the group of melt-mobile incompatible elements. These melt mobile elements include Th and the LREE, which are mobile either due to higher temperatures or as a result of sediment melting (Pearce et al., 2005; Ribeiro et al., 2013).

Figure $11 \mathrm{~b} \& \mathrm{c}$ shows N-MORB normalized spidergram of averaged Andaman basalts along with some trace element proxies. These proxies have been used to break down a typical geochemical pattern into four components viz. (a) the baseline is defined by the mantle component with a pattern that passes through the conservative (subduction-immobile) elements ( $\mathrm{Nb}, \mathrm{Zr}$, Ti, HREEs); (b) lithospheric component represented by $\mathrm{Nb} / \mathrm{Yb}$ and Ti contents; (c) deep-subduction component encompasses subduction-mobile elements $(\mathrm{Rb}, \mathrm{Ba}$, $\mathrm{Sr}, \mathrm{K}$, Th, U, LREEs, MREEs, $\mathrm{P}, \mathrm{Pb}$ ) that characterize the melt released at high temperatures from subducted crust and sediment; and (d) shal-
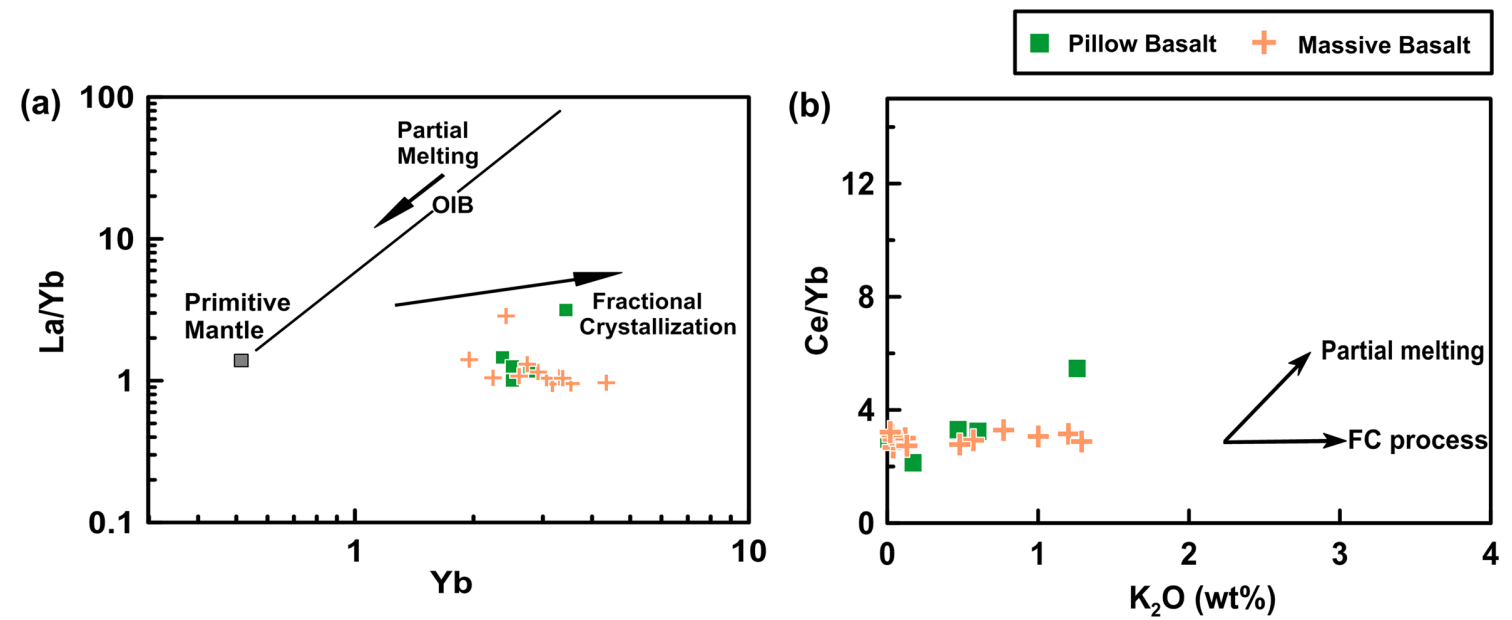

Figure 10. Variation trends of (a) La vs. La/Sm (b) $\mathrm{K}_{2} \mathrm{O}$ vs. Ce/Yb and (c) $\mathrm{Yb}$ vs La/Yb showing that fractional crystallization (FC) play important role in the magmatic evolution of the basaltic rocks in South Andaman Island Ophiolite. 

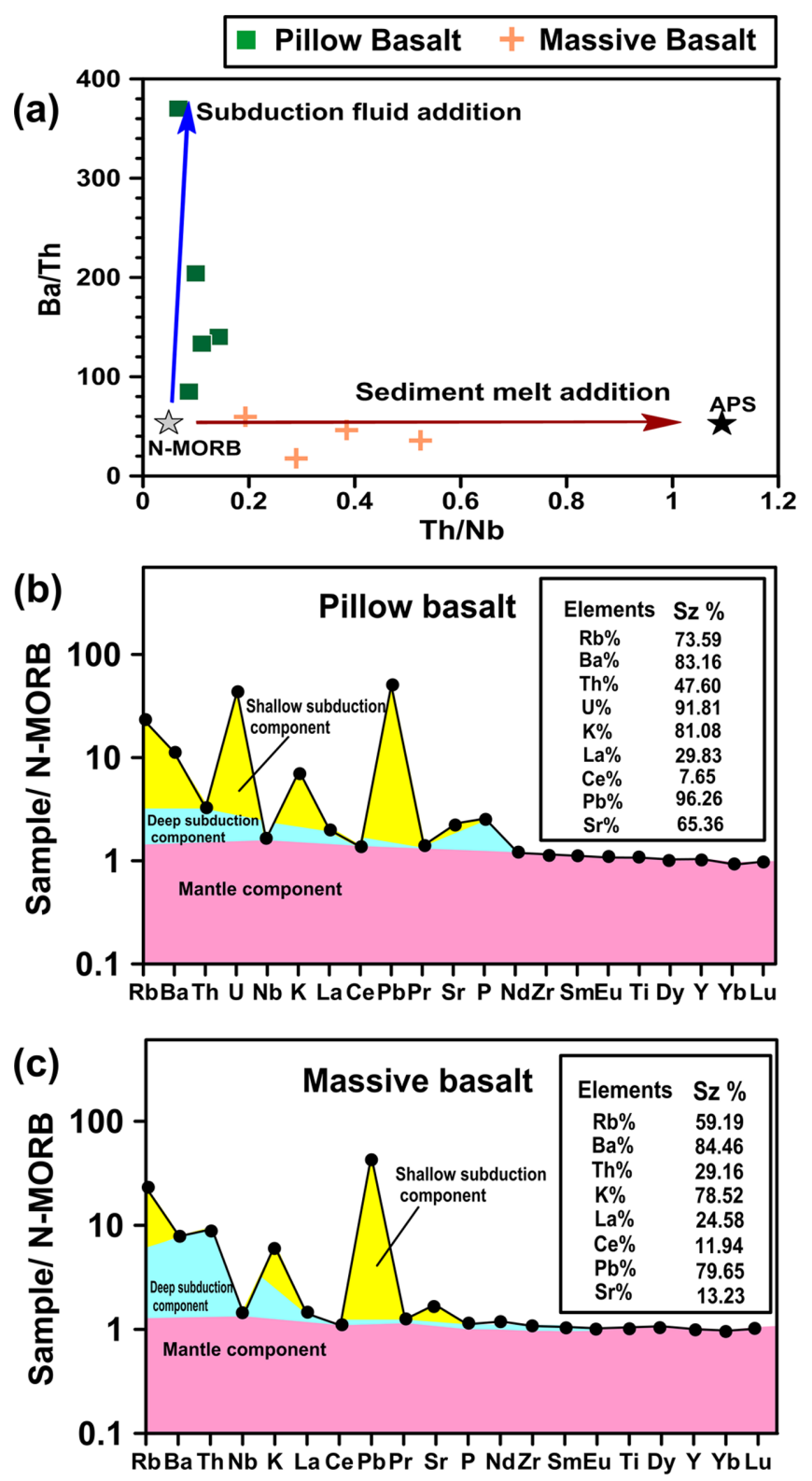

Figure 11. (a) Ba/Th vs. Th/Nb diagram for basalts of South Andaman Island Ophiolite. Stars indicate the compositions of average pelitic sediments (APS, Taylor and McLennan, 1985) and normal-type mid-ocean ridge basalt (N-MORB, Sun and McDonough, 1989). (b) \& (c) MORB normalized multi-element patterns of basalts of South Andaman Ophiolite. According to proxies $(\mathrm{Ba} / \mathrm{Nb} ; \mathrm{Ba} / \mathrm{Th} ; \mathrm{Th} / \mathrm{Nb} ; \mathrm{Nb} / \mathrm{Yb})$ for the different components (Pearce et al., 2005; Pearce and Stern, 2006), the pillow and massive basalt patterns are separated into two main components: mantle component and slab-derived component deep and shallow subduction components. MORB normalizing values from N-MORB concentrations are from Sun and McDonough (1989) ( $(\mathrm{sz} \%=$ subduction component percentage).

low-subduction (Ba-bearing) component defined by the fluid mobile elements $(\mathrm{Rb}, \mathrm{Ba}, \mathrm{K}, \mathrm{Sr}, \mathrm{Pb})$ that outline the aqueous fluid released at low temperatures from the subducted crust or sediment (McCulloch and Gamble, 1991; Johnson and Plank, 1999; Elliott, 2003; Manning, 2004; Pearce et al., 2005; Pearce and Stern 2006). As can be seen in Fig. 11b-c, using the proxies as mentioned above for our data the Andaman basalts seems to have both mantle-derived $(\mathrm{Nb})$ and slabderived $(\mathrm{Ba} / \mathrm{Nb})$ components.

\section{Magma source}

The incompatible element profiles of basalt samples from the Andaman ophiolite are characteristic of mantle-derived magmas. In the $\mathrm{Th} /$ $\mathrm{Nb}$ vs. $\mathrm{Nb} / \mathrm{Yb}$ diagram (Fig. 12), samples of pillow basalt plot within the mantle array towards the upper bound, while samples of massive basalt plot above the mantle array. Primary melts derived from garnetbearing mantle source have $(\mathrm{Gd} / \mathrm{Yb})_{\mathrm{N}}>2$ or $(\mathrm{Tb} / \mathrm{Yb})_{\mathrm{N}}>1.8$ (e.g., Rooney, 2010). In the $(\mathrm{Gd} / \mathrm{Yb})_{\mathrm{N}}$ vs. $(\mathrm{La} / \mathrm{Sm})_{\mathrm{N}}$ diagram (Fig. 13a), all basalt samples plot below $(\mathrm{Gd} / \mathrm{Yb})_{\mathrm{N}}<2$ and therefore it is likely that their primary melt originated in the spinel-bearing mantle source. Since the spinel to garnet transition in the mantle is estimated to occur at pressures of approximately 2.7 GPa ( $\sim 90 \mathrm{~km})$ (Robinson and Wood, 1998), we can infer that the source of the Andaman ophiolite basalts is less than $90 \mathrm{~km}$. Our depth estimates based on the clinopyroxene chemistry (low pressure, Fig. 6d) conforms to the whole rock geochemical results.

Magmas generated from partial melting of a garnet-lherzolite mantle source show relatively high fractionation of HREEs due to the presence of residual garnet. Whereas the magmas produced from partial melting of a spinel lherzolite source display flat MREE to HREE patterns in the chondrite-normalized diagram (Liu et al., 2018). Elements Sm and $\mathrm{Yb}$ have similar partition coefficients. Therefore, $\mathrm{Sm} / \mathrm{Yb}$ ratio does not change during partial melting, whereas $\mathrm{La} / \mathrm{Sm}$ ratio may increase with increasing degree of partial melting (Thirwall et al., 1994). Also, $\mathrm{La} / \mathrm{Sm}$ and $\mathrm{Sm} / \mathrm{Yb}$ ratios are unaffected by crystallization (Pearce, 2008; Humphreys and Niu, 2009; Liu et al., 2018). We thus use the $(\mathrm{Sm} / \mathrm{Yb})_{\mathrm{N}}$ and $(\mathrm{La} / \mathrm{Sm})_{\mathrm{N}}$ ratios in basalts under study to model partial melting.

We have adopted the non-modal batch melting equation by Shaw (1970; Eq. 15) to model the partial melting of the mantle source linked to massive and pillow basalts of the Andaman ophiolite. Modal mineral and melt proportions are from Thirwall et al. (1994). Partition coefficients have been taken from Stracke et al. (2003). Depleted MORB mantle (DMM) (Workman and Hart, 2005) has been taken as the mantle source. Average for primitive mantle (PM), N-MORB, E-MORB are from Sun and McDonough (1989). Normalizing values for REEs are from Sun and McDonough (1989). In the $(\mathrm{Sm} / \mathrm{Yb})_{\mathrm{N}}$ vs. $(\mathrm{La} / \mathrm{Sm})_{\mathrm{N}}$ diagram, all basalt samples from the study area plot close to the spinel lherzolite melting curve. This indicates that the primary melt may have been produced by approximately $2-8 \%$ of partial melting of a spinel lherzolite mantle (Fig. 13b-c).

\section{Tectono-magmatic significance and geodynamic implica- tions}

Study of the igneous rocks incorporated within ophiolitic mélanges provides strong constraints on the magmatic and geodynamic evolution of oceanic basins. Such studies reveal processes associated with continental rifting and breakup, development of oceanic lithosphere, its consumption in a subduction zone and ultimately culminating in ophiolite emplacement (e.g., Floyd et al., 1991; Tankut et al., 1998; Bortolotti et al., 2004; Moghadam and Stern, 2011; Dilek and Furnes, 2011; Pirnia et al., 2020). Changes in magmatic affinities in ophiolitic rocks usually point towards spatial and temporal variations in the geotectonic setting of the primary magma source (Dilek and Furnes, 2011; Dilek and Furnes, 2014).

The lavas of the ophiolite suite of South Andaman Island are largely 


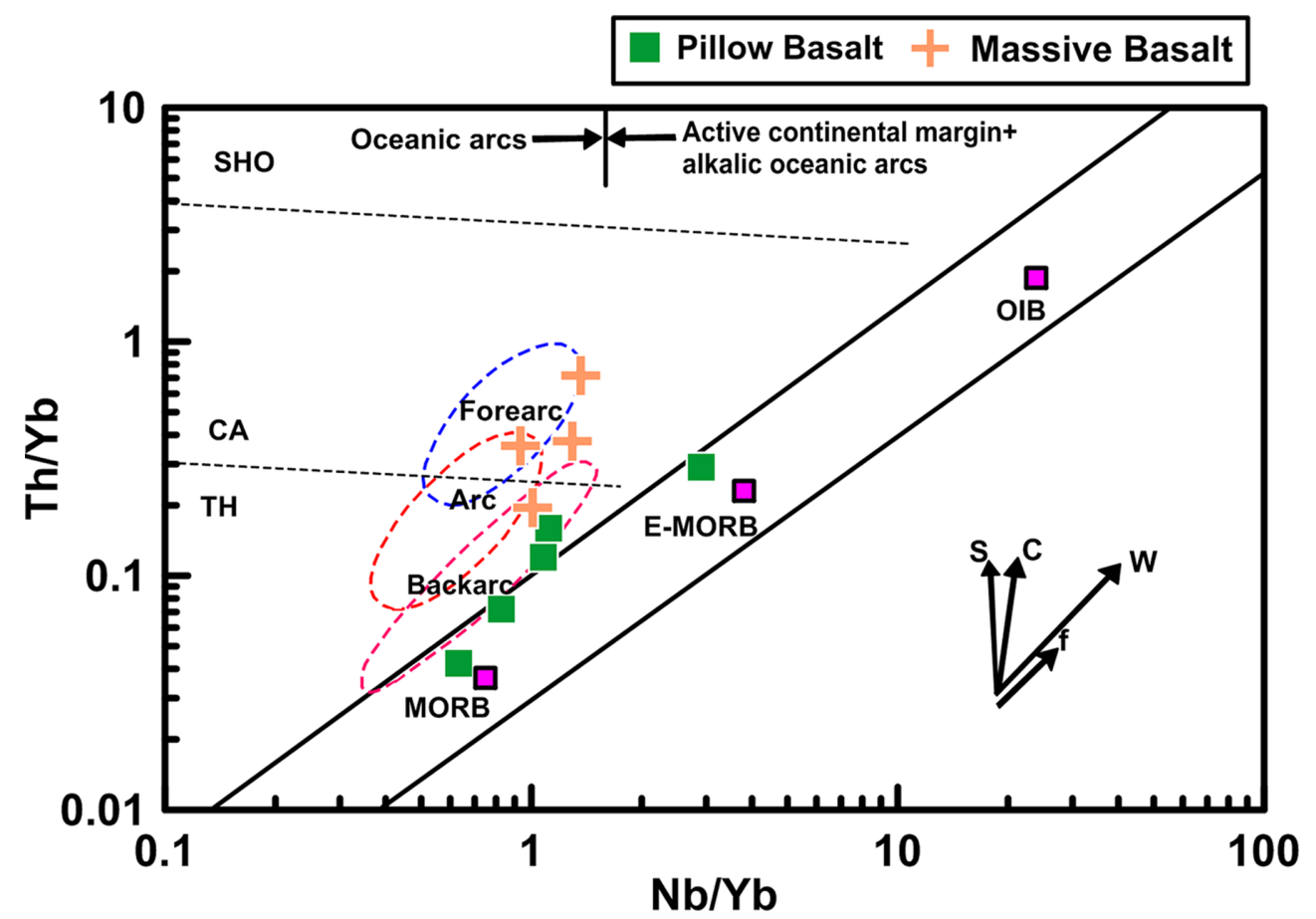

Figure 12. Tectonic discrimination diagram of $\mathrm{Nb} / \mathrm{Yb}$ versus $\mathrm{Th} / \mathrm{Yb}$ after Pearce (2008). The dashed field boundaries for $\mathrm{TH}=\mathrm{tholeiitic,CA}=\mathrm{calc}$ alkaline, and $\mathrm{SHO}=$ shoshonitic rocks are from convergent margins. The bold arrows in the bottom right are $S=$ subduction component, $C=$ crustal contaminant component, $W=$ within plate, and $f=$ fractional crystallization vectors. The South Andaman pillow and massive basalts fall within the Phanerozoic arc, fore-arc, and back-arc basalt fields are from Metcalf and Shervais (2008) proximal to the N-MORB in the terrestrial MORB mantle array and consistent with an oceanic arc origin endorsing a subduction setting.

accreted fragments of oceanic crust (Ghosh et al., 2017; Pal, 2020). As such, our sampling locations are not representative of the entire spread and nature of this specific ocean basin. It limits our ability to assess the entire gamut of geochemical changes of magmatic events that took place over the entire history of this oceanic basin. However, we have tried to assess the individual mantle source components that contributed to the processes of crust generation and the relevant tectonic setting in which the oceanic crust formed for this particular oceanic basin.

The geochemical data of massive and pillow basalts of this study were plotted on various trace element tectonic discrimination diagrams. In the $\mathrm{Zr}$ vs. Y plot, the basalts lie within tholeiite to transitional fields (Ross and Bedard, 2009) (Fig. 14). The enriched LILE (K, Rb, Ba, Sr), depleted HFSE (Nb, Ti etc.), depleted LREE and flat MREE to HREE pattern in basalts show an agreement with the typical subduction zone signatures (Pearce, 1983). All samples fall within the MORB array and display enriched feature in the $\mathrm{Zr} / \mathrm{Yb}$ vs. Nb/Yb plot (Fig. 15a) (Macdonald et al., 2000). In the Ti/Zr, Ti/Sc and Ti/V vs. Zr plots, most samples fall in the back-arc field (Gribble et al., 1996; Polat et al., 1999) (Fig. 15b, c, d). In the $\mathrm{Th} / \mathrm{Yb}$ vs. Nb/Yb diagram, pillow basalt samples fall largely within the MORB array, while massive basalt samples are displaced to higher $\mathrm{Th} / \mathrm{Yb}$ towards oceanic arc systems (See Fig. 12). In the $\mathrm{V}$ vs. Ti/1000 discrimination diagram, all the samples from South Andaman ophiolite show BAB-MORB (BAB: back arc basin) characteristics (Fig. 16a). The analyzed data show compositional overlap between N-MORB and Back-Arc Basin Basalt (BABB) in the $\mathrm{Al}_{2} \mathrm{O}_{3}$ vs. $\left(\mathrm{TiO}_{2}+\mathrm{Cr}_{2} \mathrm{O}_{3}\right)$ diagram for clinopyroxenes of basalts from the South Andaman Island ophiolites (adapted after Hout et al., 2002) (Fig. 16b). In the context of our findings we need to ascertain whether these studied BABB developed in an intra-oceanic arc (e.g., South Sandwich Islands, Tonga-Kermadec arcs, Mariana back-arc basin, Gribble et al., 1996) or an intra-continental arc (e.g., Ryukyu back-arc basin, Shinjo et al., 1999). The intra-oceanic BABB generally have $(\mathrm{La} / \mathrm{Yb})_{\mathrm{N}}<2, \mathrm{Nb} / \mathrm{La}$ $<0.6, \mathrm{Sm} / \mathrm{Nd}>0.3$ (Hawkins, 1995), whereas the intra-continental BABB developed from a continental basement usually exhibit EMORB-like elemental and isotopic compositions with $(\mathrm{La} / \mathrm{Yb})_{\mathrm{N}}>3$, $\mathrm{Nb} / \mathrm{La}>0.6$ and $\mathrm{Sm} / \mathrm{Nd}<0.3$ (Shinjo et al., 1999). The South Andaman MORB-like pillow basalts have $(\mathrm{La} / \mathrm{Yb})_{\mathrm{N}}=0.72-2.27$ (Average $=1.15), \mathrm{Nb} / \mathrm{La}=0.08-1.07($ Average $=0.63)$ and $\mathrm{Sm} / \mathrm{Nd}=0.27-0.35$ (Average $=0.33)$ and the South Andaman arc-like massive basalts have $(\mathrm{La} / \mathrm{Yb})_{\mathrm{N}}=0.68-2.05($ Average $=0.89), \mathrm{Nb} / \mathrm{La}=0.48-1.28($ Average $=0.98)$ and $\mathrm{Sm} / \mathrm{Nd}=0.29-0.36($ Average $=0.34)$ similar to those of the intra-oceanic BABB. Presented tectonic discrimination diagrams and geochemical composition of the studied basalts suggests an oceanic back-arc basin to be the site for the generation of South Andaman Island basaltic extrusives. Existence of extrusive basaltic rocks with a clear geochemical character of back-arc basin indicates a single stage of crust generation in an oceanic environment for this ophiolite suite.

Back-arc basins are regions of extension at convergent plate margins where rifting, and in some cases, seafloor spreading develops on the overriding plate (Pearce et al., 1994; Pearce and Stern, 2006). Sdrolias and Müller (2006) through their extensive work have demonstrated that the geometry of slab subduction, the effect of lateral mantle flow on the slab, and mantle wedge dynamics has a strong bearing on the formation mechanism of a back-arc basin. Generally, back-arc basin development results from the subduction of an old oceanic slab (Sdro- 

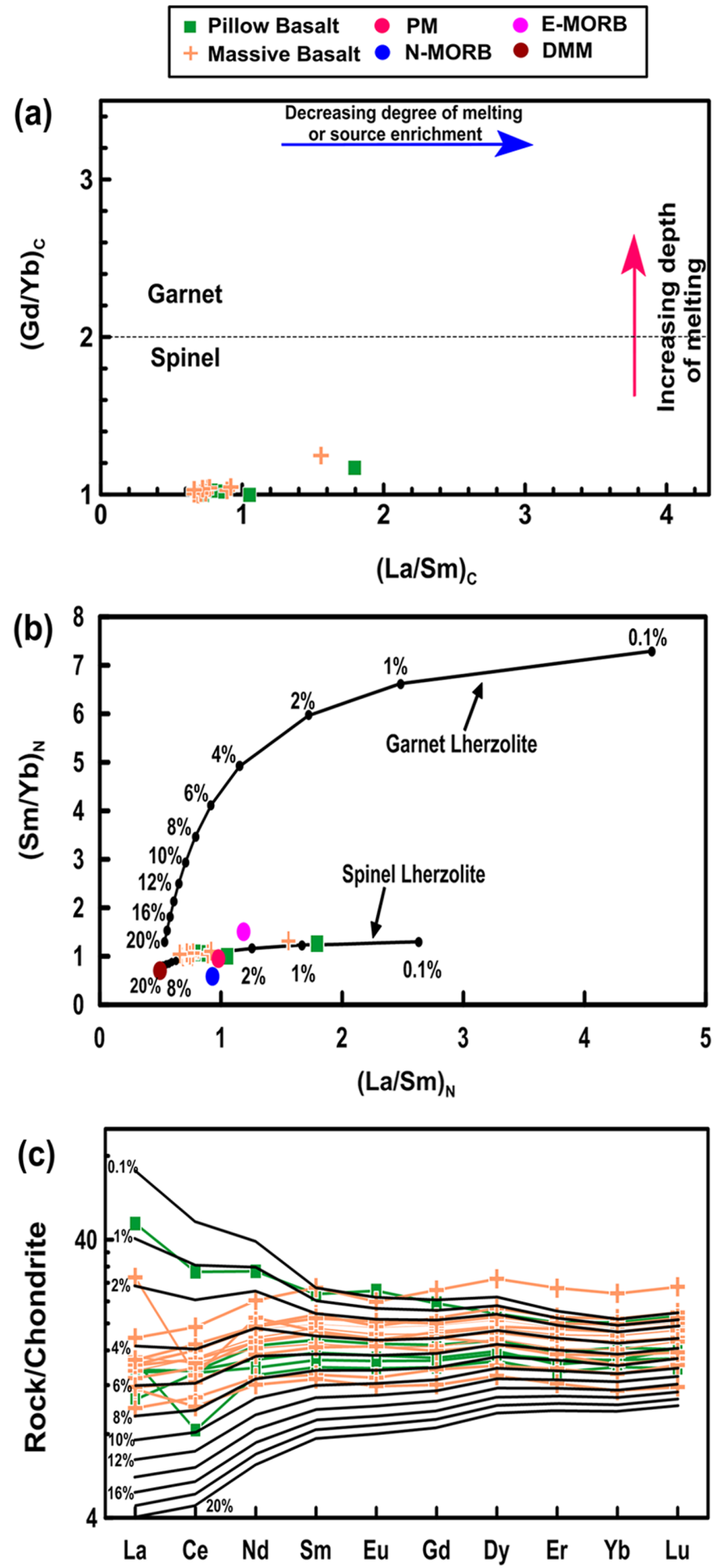

Figure 13. (a) The $(\mathrm{La} / \mathrm{Sm})_{C}$ vs. $(\mathrm{Gd} / \mathrm{Yb})_{C}$ diagram points to a spinel-bearing source for pillow and massive basalts of South Andaman Island Ophiolite. Normalization values of the chondrite C1 after Sun and McDounough (1989). (b) $(\mathrm{Sm} / \mathrm{Yb})_{N}$ versus $(\mathrm{La} / \mathrm{Sm})_{N}$ chondrite-normalized plots showing melting curves for non-modal, batch melting of garnet and spinel lherzolite with depleted MORB mantle as the source composition. All the studied basalts seem to have originated from $<8 \%$ partial melting of a spinel Iherzolite source. Modal mineral and melt proportions are from Thirlwall et al., (1994). Garnet lherzolite:- mineral mode $57.8 \%$ olv, $21.1 \%$ opx, 7.6\% cpx, $11.5 \%$ gt and melt mode $5 \%$ olv, 20\% opx, 30\% cpx, 45\% gt. Spinel Iherzoloite:- mineral mode $57.8 \%$ olv, 20\% opx, $11.9 \%$ cpx, 3.3\% sp and melt mode $10 \%$ olv, $27 \%$ opx, $50 \%$ cpx, $13 \%$ sp. Tick marks on melt curves represent degree of melting (F). Partition coefficients have been taken from Stracke et al., (2003). Non-modal, batch melting model is from Shaw (1970, Eq. 15). Average for PM, N-MORB, E-MORB are from Sun and McDonough (1989) and DMM from Workman and Hart (2005). Normalizing values are from Sun and McDonough (1989). N-MORB: Normal Mid-Ocean Ridge Basalt, E-MORB: Enriched Mid-Ocean Ridge Basalt, DMM: Depleted MORB Mantle, olv: olivine, opx: orthopyroxene, cpx: clinopyroxene, sp: spinel, gt: garnet. and (c) Calculated chondrite-normalized (Sun and McDonough, 1989) rare earth element patterns for parental melts derived for spinel lherzolite mantle source, assuming various degrees of non-modal batch melting according to the parameters (source modes, meling proportions, etc.) listed in caption (b) above.

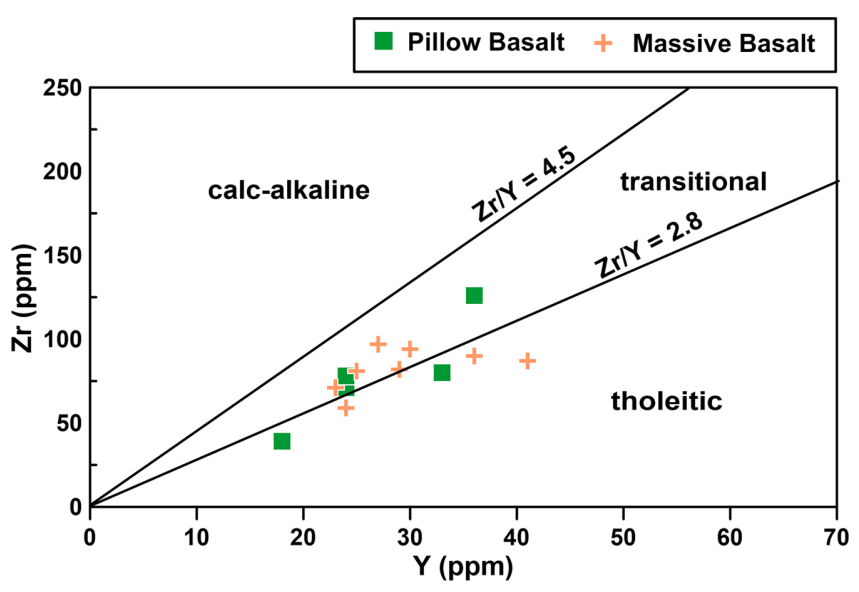

Figure 14. Zr vs. Y plot showing the tholeiitic to transitional affinity of the basalts of (after Ross and Bedard, 2009).

lias and Müller, 2006). With the initiation of subduction due to viscous drag of subducting slab, a wedge mantle flow develops beneath the overriding plate. It results in circulation of mantle flow, which triggers decompression melting in the overriding lithosphere leading to the formation of a decompression spreading center beneath the plate. Due to the on-going mantle flow migration, the back-arc lithosphere tends to thin and weaken, and decompression melting ensues (Vogt et al., 2012). Furthermore, the viscous drag of mantle flow moves the overriding plate towards the trench direction, and an active volcanic rifting gets initiated (Capitanio et al., 2010). The roll-back of subduction hinge provides sufficient room which promotes further spreading of the back-arc basins (Sdrolias and Müller, 2006; Nakakuki and Mura, 2013, Gao et al., 2018; Zhu et al., 2020).

The evolution of a back-arc basin is typically accompanied with extensive volcanic magmatism forming island arc basalts (IAB), BABB and MORB-like basalts due to varying contributions of subducted materials (Pearce et al., 1994; Pearce and Stern, 2006; Kelley et al., 2006; Langmuir et al., 2006; Gao et al., 2018; Zhu et al., 2020). Presence of these rock assemblages in back-arc basins divulges that the volume of subduction components in the metasomatized mantle sources vary with variable distances from the trench (Pearce et al., 1994; Pearce and Stern, 2006). During the initial phase of back-arc extension closer to the trench arc-like magma erupts. N-MORB-like magma erupts in the later stages of back-arc spreading away from the trench because their chemical composition is relatively less affected by the subducting slab. Assemblages of arc-like and MORB-like basalts has been widely reported from many back-arc basin settings world over, like in the Mariana trench, Lau basin and Tonga basin, Andaman Basin (Hawkins, 1995; 


\section{Pillow Basalt + Massive Basalt}
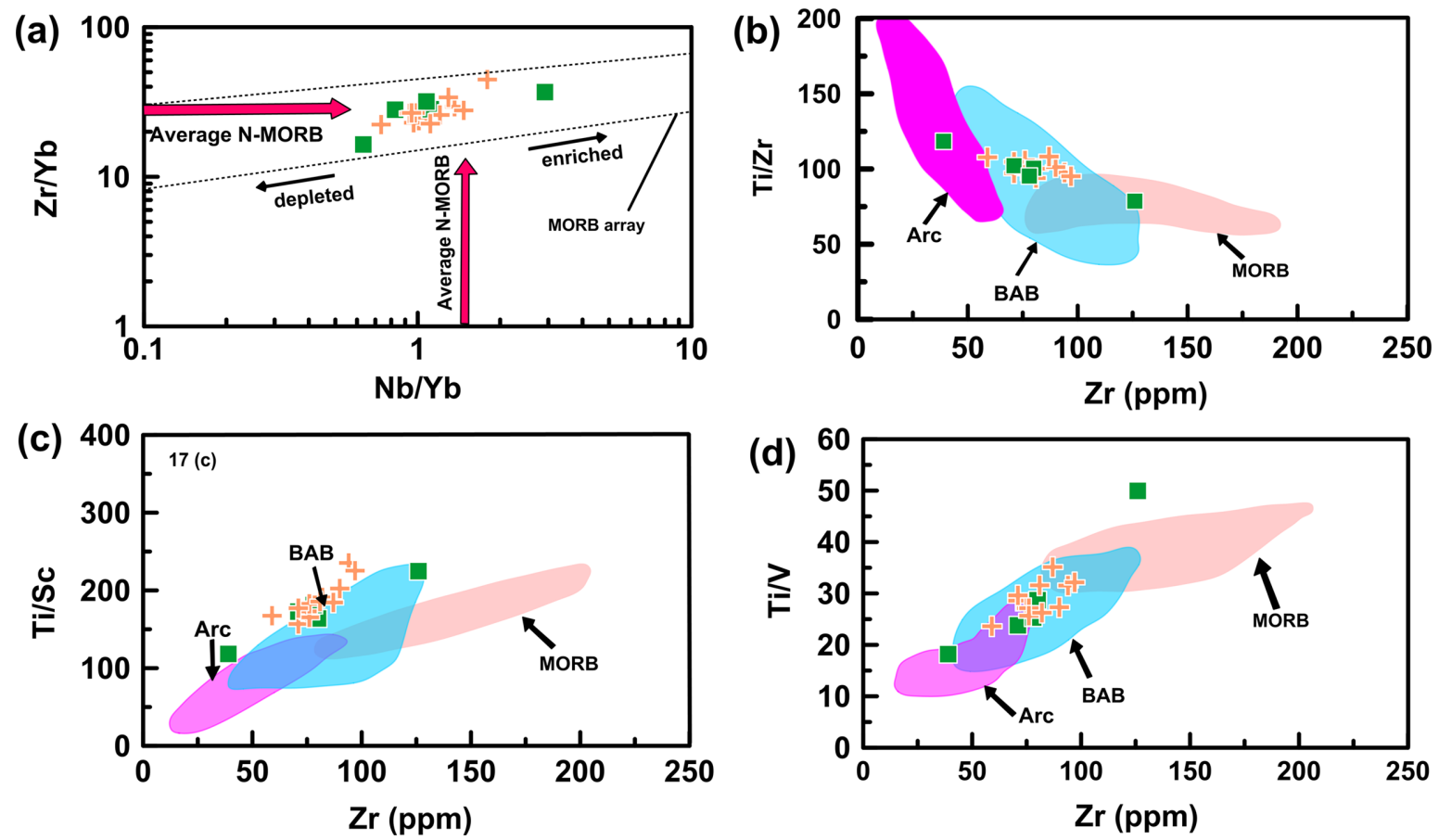

Figure 15. (a) $\mathrm{Zr} / \mathrm{Yb}$ vs. $\mathrm{Nb} / \mathrm{Yb}$ (modified from Macdonald et al., 2000) plot indicating an average $\mathrm{N}$-MORB composition of the pillow and massive basalt for the South Andaman Island Ophiolite (b) Ti/Zr, Ti/Sc, Ti/V vs. Zr, after Gribble et al. (1996) and Polat et al. (1999) showing back-arc setting for the South Andaman Island Ophiolite.
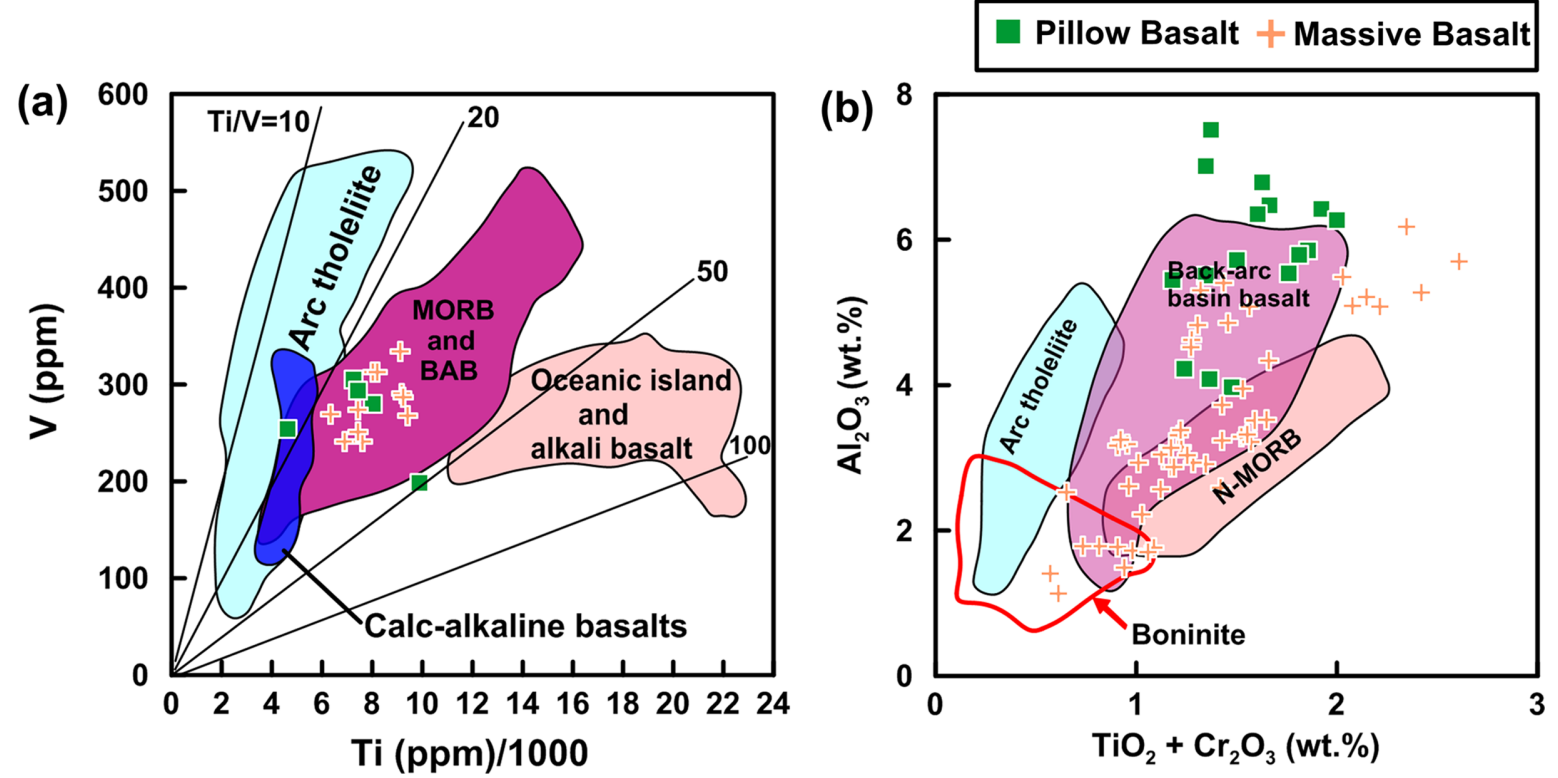

Figure 16. (a) Ti versus V plot of the Basalts of South Andaman Island Ophiolite (Ti/V ratios are characteristics of: 10-20 = island arcs; $20-50=$ midoceanic ridge basalt (MORB); 20-30 = mixed MORB and island arc; 10-50 = back-arc basins; and boninite field, diagram after Shervais, (1982) (b) $\mathrm{Al}_{2} \mathrm{O}_{3}$ vs. $\left(\mathrm{TiO}_{2}+\mathrm{Cr}_{2} \mathrm{O}_{3}\right)$ diagram (adapted after Hout et al., 2002). of clinopyroxene composition of the basalts of South Andaman Island ophiolites with the analyzed data plotting in the overlap area between N-MORB and back-arc basin basalt. Fields outline clinopyroxene compositions in boninites (VanderLaan et al., 1992), island-arc tholeiites and back-arc basin basalts (Hawkins and Allan, 1994), and N-MORB (Stakes and Franklin, 1994).

Shinjo et al., 1999; Sandeman et al., 2006; Masuda and Fryer, 2015; Saha et al., 2018; Boniface and Tsujimori, 2019; Bonnet et al., 2020). Geophysical findings by Wendt et al., 1997; Sdrolias et al., 2004; Falloon et al., 2007; Trua et al., 2007; Piauilino et al., 2019 has also reported signatures of mantle plume or hot spots as well in some of the backarc basins. There is also report of arc-like basalts, high-Mg andesites, $\mathrm{BABB}$ and OIB-like basalts (mantle plume origin) in the Caribbean back-arc basin (Escuder-Viruete et al., 2008). 

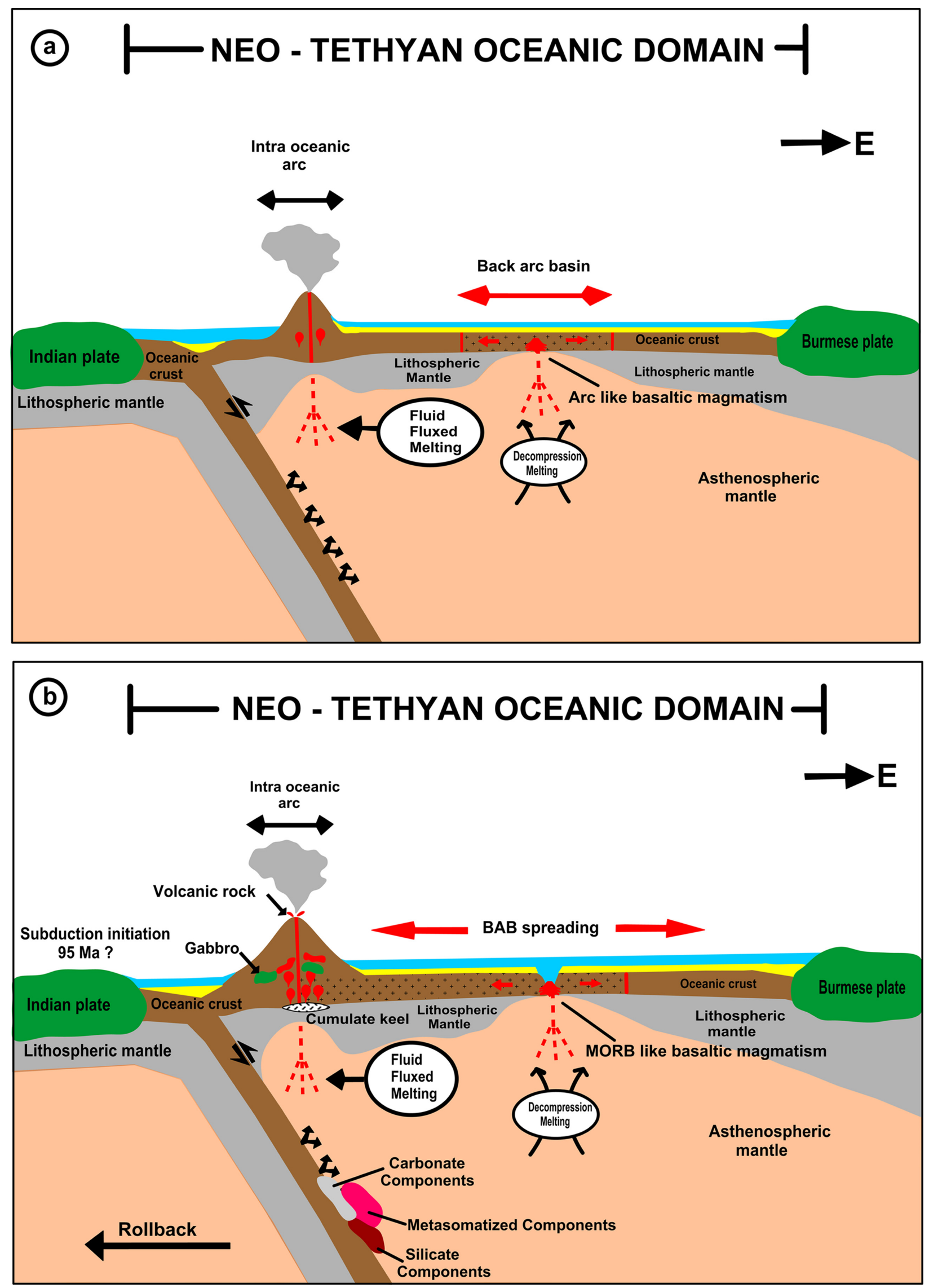

Figure 17. Late Cretaceous evolution model of the Neotethyan back-arc basin which was the site of basaltic magma generation found preserved in the South Andaman Island Ophiolite suite of India. 
The arc-like massive basalt and MORB-like pillow basalt assemblage observed in the South Andaman Island Ophiolite advocates their probable origin in a back-arc basin setting. The massive basalts with arc-like characteristics represent the earlier products of back-arc extension generated before the initial rifting of the back-arc basin. On the other hand, the MORB-like pillow basalts have formed during later stages of back-arc spreading in response to the roll-back of the subducting slab. Circulations of wedge mantle flow triggered the initial migration of the overriding plate. It also started the initial rifting of the Andaman active arc and afterwards induced back-arc extension of the Neotethyan back-arc basin (Fig. 17a). The slab roll-back induced trench-ward migration of the overriding plate, consequently further spreading of the Neotethyan back-arc basin ensued (Fig. 17b). Our findings specify that the back-arc pillow and massive basaltic lavas of South Andaman Island ophiolite are similar to the Cretaceous suprasubduction zone ophiolite of the Tethyan ocean systems.

\section{Conclusions}

The petrological and geochemical studies of the pillow and massive basalts from South Andaman Island ophiolite yield the following conclusions:

(1) The crystallization sequence of minerals in the basalts of the South Andaman Island ophiolite is plagioclase $\pm \mathrm{Cr}$-Spinel $\rightarrow$ clinopyroxene + plagioclase $\pm \mathrm{Fe}$-Ti oxide.

(2) The South Andaman Island ophiolitic basalts are tholeiitic and show enrichment in incompatible elements, depletion in $\mathrm{Nb}$ and $\mathrm{Ti}$, and contain low La/Nb ratios (0.43-1.28), comparable to the BABB signatures.

(3) The mafic extrusives display variable enrichment in LILE and depletion in HFSE, suggesting that subduction processes modified the mantle beneath the basin. Fluid mobile LILE / immobile HFSE ratios indicate that the subduction components were mainly fluid-derived released during the dehydration process from the downgoing altered oceanic crust. Contributions from subducted sediments were minor.

(4) Low to moderate degree (2-8\%) of partial melting of a spinel lherzolitic mantle source generated the primary melt of South Andaman Island ophiolite basalts.

(5) The South Andaman Island ophiolitic basalts were generated in an oceanic back-arc setting.

\section{Acknowledgements}

Authors acknowledge Delhi University Research and Development Grant (2011-12) and CSIR JRF/SRF fellowship no. 09/045 (1358)/ 2015-EMR-1. We duly acknowledge Mr. Rajeev Kumar for help with fieldwork and Prof. S. C. Patel, IIT, Mumbai, (India) for EPMA facility.

\section{References}

Acharyya, S.K., 2010, Tectonic evolution of Indo-Burma range with special reference to Naga-Manipur Hills. Memoir Geological Society India, v. 75, pp. 25-43.

Acharyya, S.K., 2015, Indo-Burma Range: A belt of accreted microcontinents, ophiolites and Mesozoic-Paleogeneflyschoid sediments. Inter- national Journal of Earth Sciences, v. 104, pp. 1235-1251. doi:10.1007/ s00531-015-1154-6

Allen, R., Carter, A., Najman, Y., Bandopandhyay, P.C., Chapman, H.P., Bickle, M.J., Garzanti, E., Vezzoli, G., Ando, S., Foster, G.L. and Gerring, C., 2007, New constraints on the sedimentation and uplift history of the Andaman-Nicobar accretionary prism, South Andaman Island. In: Draut, A., Clift, P.D. \& Scholl, D.W. (eds.) Formation and Applications of the Sedimentary Record in Arc Collision Zones, vol. 436. Geological Society of America, Special Papers, pp. 223-255. doi:10.1130/ 2007.2436(11)

Arai, S., 1992, Chemistry of chromian spinel in volcanic rocks as a potential guide to magma chemistry. Mineralogical Magazine, v. 56, pp. 173184. doi:10.1180/minmag.1992.056.383.04

Aitchison, J. C., Ao, A., Bhowmik, S.,Clarke, G. L., Ireland, T. R.,Kachovich, S., Lokho, K., Stojanovic, D., Roeder, T., Truscott, N., Zhen, Y., and Zhou, R., 2019, Tectonicevolution of the western margin of the Burma microplate based on new fossiland radiometric age constraints. Tectonics, v. 38, pp. 1718-1741. doi:10.1029/2018TC005049

Balaram, V., Saxena, V.K, Manikyamba, C. and Ramesh, S.L., 1990, Determination of rare earth elements in Japanese rock standards by inductively coupled plasma mass spectrometry. Atomic Spectroscopy, v. 11, pp. 19-23. doi:10.1021/ac00135a018

Bandyopadhyay, D., van Hinsbergen, D.J.J., Plunder, A., Bandopadhyay, P.C., Advokaat, E.L., Morishita, T., and Ghosh, B., 2020, Andaman Ophiolites: an overview. In J.S. Ray \& M. Radhakrishna (Eds.), The Andaman Islands and Adjoining Offshore: Geology, Tectonics and Paleoclimate. Springer Nature Switzerland AG 2020. doi:10.1007/ 978-3-030-39843-9_1

Baxter, A.T., Aitchison, J.C., Zyabrev, S. V. and Ali, J.R., 2011, Upper Jurassic radiolarians from the Naga Ophiolite, Nagaland, northeast India. Gondwana Research, v. 20, pp. 638-644. doi:10.1016/j.gr. 2011.02.001

Beccaluva, L., Macciotta, G., Piccardo, G.B. and Zeda, O., 1989, Clinopyroxene compositions of ophiolite basalts as petrogenetic indicator. Chemical Geology, v. 77, pp. 165-182. doi:10.1016/0009-2541(89) 90073-9

Bhat, G.R., Balaji, S., Iqbal, V., Balakrishna, B. and Yousuf, M. 2019, Neotectonics and related crustal deformation along Carbyn thrust fault, South Andaman, India: implications of the frontal surface faulting and propagation of tectonic activity towards Andaman trench: Arabian Journal of Geosciences, v. 2, pp. 149. doi:10.1007/s12517-019-4282-7

Bhattacharya, A., Pal, T., and Ghosh, B., 2013, Characterization of the accreted Ophiolite slices of Rutland island, Andaman sea: Evolution in a Suprasubduction zone setting, Ofioliti, v. 38, pp. 121-142. doi:10.4454/ ofioliti.v38i2.422

Bonev, N., and Stampfli, G., 2008, Petrology, geochemistry and geodynamic implications of Jurassic island arc magmatism as revealed by mafic volcanic rocks in the Mesozoic low-grade sequence, eastern Rhodope, Bulgaria. Lithos, v. 100, pp. 210-233. doi:10.1016/j.lithos.2007.06.019

Boniface, N., and Tsujimori, T. 2019, Pillow lava basalts with back-arc MORB affinity from the Usagaran Belt, Tanzania: relics of Orosirian ophiolites. Journal of the Geological Society, London, v. 176, pp. 1007-1021. doi:10.1144/jgs2018-205

Bonnet, G., Agard, P., Whitechurch, H., Fournier, M., Angiboust, S, Caron, B., and Omran, J., 2020, Fossil seamount in southeast Zagros records intra oceanic arc to back-arc transition: New constraints for the evolution of the Neotethys. Gondwana Research, v. 81, pp. 423-444. doi:10.1016/ j.gr.2019.10.019

Bortolotti, V., Chiari, M., Kodra, A., Marcucci, M., Mustafa, F., Principi, G., and Saccani, E., 2004, New evidence for Triassic MORB magmatism in the northern Mirdita Zone ophiolites (Albania). Ofioliti, v. 29, pp. 243-246.

Capitanio, F.A., Stegman, D.R., Moresi, L.N., and Sharples, W., 2010, Upper plate controls on deep subduction, trench migrations and deformations at convergent margins, Tectonophysics, v. 483, pp. 80-92. 
doi:10.1016/j.tecto.2009.08.020

Caulfield, J.T., Turner, S.P., Dosseto, A., Pearson, N.J., and Beier, C., 2008, Source depletion and extent of melting in the Tongan sub-arc mantle. Earth and Planetary Science Letters, v. 273, pp. 279-288. doi:10.1016/j.epsl.2008.06.040

Cawood, P.A., Kröner, A., Collins, W.J., Kusky, T.M., Mooney, W.D., and Windley, B.F., 2009, Accretionary orogens through Earth history. In: Cawood, P.A. and Kröner, A. (Eds.), Earth Accretionary Systems in Space and Time. Geological Society of London, Special Publication, v. 318, pp. 1-36. doi:10.1144/SP318.1

Cloos, M., 1993, Lithosphere buoyancy and collisional orogenesis: Subduction of oceanic plateaus, continental margins, island arcs, spreading ridges, and seamounts. Geological Society of America Bulletin, v. 105, pp. 715-737. doi:10.1130/0016-7606(1993)105<0715: LBACOS > 2.3.CO;2

Dick, H.J.B., and Bullen, T., 1984, Chromium spinel as a petrogenetic indicator in abyssal and alpine-type peridotites and spatially associated lavas. Contributions to Mineralogy and Petrology, v. 86, pp. 54-76. doi:10.1007/BF00373711

Dilek, Y., 2003, Ophiolite concept and its evolution. In: Dilek, Y., and Newcomb, S., eds., Geological Society of America Special Paper, Ophiolite Concept and the Evolution of Geological Thought, v. 373, pp. 1-16. doi:10.1130/0-8137-2373-6.1

Dilek, Y., and Flower, M.F.J., 2003, Arc-trench roll-back and forearc accretion: 2. A model template for ophiolites in Albania, Cyprus, and Oman in Dilek, Y. and Robinson, P.T. eds., Ophiolites in Earth History, vol 218. Geological Society of London Special Publication. pp. 43-68. doi:10.1144/GSL.SP.2003.218.01.04

Dilek, Y., and Furnes, H., 2011, Ophiolite genesis and global tectonics: Geochemical and tectonic fingerprinting of ancient oceanic lithosphere. Geological Society of America Bulletin, v. 123, pp. 387-411. doi:10.1130/B30446.1

Dilek, Y., and Furnes, H., 2014, Ophiolite and Their Origins. Elements, v. 10, pp. 93-100. doi:10.2113/gselements.10.2.93

Elthon, D., 1987, Olivine-liquid partitioning in high-MgO basalt and komatites, In: 18th Lunar and Planetary Science Conference, pp. 258-259.

Elliott, T., 2003, Tracers of the slab. In: John Eiler (Eds), Inside the Subduction Factory, vol 138. Geophysical Monograph, pp. 23-45. doi:10.1029/138GM03

Escuder-Viruete, J., Joubert, M., Urien, P., Friedman, R., Weis, D., Ullrich, T., and Pérez-Estaún, A., 2008, Caribbean island-arc rifting and back-arc basin development in the Late Cretaceous: geochemical, isotopic and geochronological evidence from Central Hispaniola. Lithos, v. 104, pp. 378-404. doi:10.1016/j.lithos.2008.01.003

Ewart, A., Bryan, W.B., Chappell, B.W., and Rudnick, R.L., 1994, Regional geochemistry of the Lau-Tonga arc and back-arc systems. In: Hawkins, J., Parson, L., Allan, J., et al. (Eds.), Proceedings of the Ocean Drilling Program. Scientific Results 135. Ocean Drilling Program, College Station, TX, pp. 385-425. doi:10.2973/odp.proc.sr.135.141.1994

Falloon, T.J., Danyushevsky, L.V., Crawford, A.J., Maas, R., Woodhead, J.D., Eggins, S.M., Bloomer, S.H., Wright, D.J., Zlobin, S.K., and Stacey, A. R., 2007, Multiple mantle plume components involved in the petrogenesis of subduction related lavas from the northern termination of the Tonga Arc and northern Lau Basin: evidence from the geochemistry of arc and back-arc submarine volcanics. Geochemistry, Geophysics, Geosystems, v. 8, pp. 1. doi:10.1029/2007GC001619

Fareeduddin, F., and Dilek, Y., 2015, structure and petrology of the NagalandManipur Hill Ophiolitic Mélange Zone, NE India: A Fossil Tethyan Subduction Channel at the India - Burma Plate Boundary. Episodes, v. 38, pp. 298-314. doi:10.18814/epiiugs/2015/v38i4/82426

Floyd, P.A., Kelling, G., Gocken, S.L., and Gocken, N., 1991, Geochemistry and tectonic environment of basaltic rocks from the Miss ophioliticmelange, south Turkey. Chemical Geology, v. 89, pp. 263-280. doi:10.1016/ 0009-2541(91)90020-R

Gao, Z., Zhang, H.F., Yang, H., Fa-Bin Pan, F.B., Bi-JiLuo, B.J., Guo, L., Xu, W.C., Tao, L., Zhang, L.Q., and Wu, J., 2018, Back-arc basin develop- ment: Constraints on geochronology and geochemistry of arc-like and OIB-like basalts in the Central Qilian block (Northwest China), Lithos, v. 310-311, pp. 255-268. doi:10.1016/j.lithos.2018.04.002

Gardien, V., Lécuyer, C., and Moyen, J.F., 2008, Dolerites of the Woodlark Basin (Papuan Peninsula, New Guinea): A geochemical record of the influence of a neighbouring subduction zone. Journal of Asian Earth Sciences, v. 33, pp.139-154. doi:10.1016/j.jseaes.2007.12.003

Ghosh, B., and Bhatta, K., 2014, Podiform chromitites in lherzolitic mantle rocks (Andaman ophiolite, India): The role of magma/rock interaction and parental melt composition. Bulletin de la SocieteGeologique de France, v. 185, pp. 123-130. doi:10.2113/gssgfbull.185.2.123

Ghosh, B., Morishita, T., Gupta, B.S., Tamura, A., Arai, S., and Bandyopadhyay, D., 2014, Moho transition zone in the Cretaceous Andaman ophiolite, India: a passage from the mantle to the crust. Lithos, v. 198199, pp. 117-128. doi:10.1016/j.lithos.2014.03.027

Ghosh, B., Bandyopadhyay, D. and Morishita, T., 2017, Andaman-Nicobar ophiolites, India: Origin, Evolution and Emplacement. In: Bandopadhyay, P C, Carter A. (Eds), The Andaman-Nicobar Accretionary Ridge: Geology, Tectonics and Hazards, v. 47. Geological Society of London, pp. 95-110. doi:10.1144/M47.7

Gray, D.R., Gregory, R.T., and Miller, J., 2000, A new structural profile along the Muscat-Ibra transect, Oman: Implications for emplacement of the Samail ophiolite. In: Ophiolites and Oceanic Crust: New Insights from Field Studies and the Ocean Drilling Program. Geological Society of America Special Paper, v. 349, pp. 513-523. doi:10.1130/0-8137-2349-3.513

Gribble, R.F., Stern, R.J., Bloomer, S.H., Stüben, D., O'Hearn, T., and Newman, S., 1996, MORB mantle and subduction components interact to generate basalts in the southern Mariana Trough back-arc basin. Geochimica et Cosmochimica Acta, v. 60, pp. 2153-2166. doi:10.1016/ 0016-7037(96)00078-6

Haldar, D., 1984, Some aspects of the Andaman Ophiolite Complex; Rec. Geological Survey of India, v. 119, pp. 1-11.

Hamilton, W., 1978, Tectonic map of the Indonesian region; Folio of the Indonesian Region map I-875-D, Department of the Interior, US Geological Survey. doi:10.3133/i875D

Hawkins, J.W., and Allan, J.F., 1994, Petrologic evolution of Lau Basin sites 834 through 839. In: Hawkins, J.W., et al. (Eds.), Proceedings of the Ocean Drilling Program, Scientific Results, College Station, Texas, Ocean Drilling Program, v. 135, pp. 427-470.

Hawkins, J.W., 1995, The geology of the Lau Basin. In: Taylor, B. (Ed.), Back-arc basins: Tectonics and Magmatism, Plenum Press, New York, pp. 63-138.

Hey, M.H., 1954, A new review of the chlorites: Mineralogical Magazine, v. 30, pp. 277-292. doi:10.1180/minmag.1954.030.224.01

Hout, F., Hebert, R., Varfalvy, V., Beaudoin, G., Wang, C.S., Liu, Z.F., Cotten, J., and Dostal, J., 2002, The Beimarang melange (southern Tibet) brings additional constraints in assessing the origin, metamorphic evolution and obduction processes of the YarlungZangboophiolite. Journal of Asian Earth Sciences, v. 21, pp. 307-322. doi:10.1016/S1367-9120(02)00053-6

Humphris, S.E., and Thompson, G., 1978, Trace element mobility during hydrothermal alteration of oceanic basalts. Geochimica et Cosmochimica Acta. v. 42, pp.127-136. doi:10.1016/0016-7037(78)90222-3

Humphris, S., 1984, The mobility of the rare earth elements in the crust. In Rare Earth Geochemistry Developments in Geochemistry 2 (P. Henderson, ed.). Elsevier, Amsterdam, 317-42. doi:10.1016/B978-0-44442148-7.50014-9

Humphreys, E.R., and Niu, Y.L., 2009, On the composition of ocean island basalts (OIB): The effects of lithospheric thickness variation and mantle metasomatism, Lithos, v. 112, pp. 118-136. doi:10.1016/j.lithos.2009.04.038

Jafri, S.H., 1986, Occurrence of Hagistrids in chert associated with Port Blair Series, South Andaman, India. Journal of the Geological Society of India, v. 28, pp. 41-43.

Jafri, S.H., Balaram, V., and Ramesh, S.L., 1990, Geochemistry of Andaman-Nicobar Island basalts: a case for a possible plume origin. Journal of Volcanology and Geothermal Research, v. 44, pp. 339-347. doi:10.1016/ 


\section{7-0273(90)90026-C}

Jafri, S.H., and Charan, S.N., 1992, Quench textures in pillow basalt from the Andaman- Nicobar Islands, Bay of Bengal, India. Proceedings of the Indian Academy of Science (Earth and Planetary Sciences), v. 101, pp. 99-107. doi:10.1007/BF02839176

Jafri, Sh., Balaram, V., and Govil, P., 1993, Depositional environments of Cretaceous radiolarian cherts from Andaman-Nicobar Islands, northeastern Indian Ocean. Marine Geology, v. 112, pp. 291-301. doi:10.1016/ 0025-3227(93)90174-T

Jafri, S.H., Charan S.N., and Govil P.K., 1995, Plagiogranite from the Andaman ophiolite belt, Bay of Bengal, India. Journal of Geological Society, v. 152, pp. 681-687. doi:10.1144/gsjgs.152.4.0681

Jafri, S.H., Subba Rao, M.V., and Ramesh, S.L., 2006, occurrence of ash beds in radiolarian cherts from South Andaman Island, Bay of Bengal, India: Evidence for Late Cretaceous explosive volcanism. Current Science, v. 91, pp. 1614-1615.

Jafri, S.H., Sarma, D.S., and Sheikh, J.M., 2010, Hyaloclastites in pillow basalts, South Andaman Island, Bay of Bengal, India. Current Science, v. 99, pp. 1825-1829.

Jafri, S.H., and Sheikh, J.M., 2013, Geochemistry of pillow basalts from Bompoka, Andaman-Nicobar Islands, Bay of Bengal, India. Journal of Asian Earth Science, v. 64, pp. 27-37. doi:10.1016/j.jseaes.2012.11.035

Jafri, S.H., Sarma, D.S., Khan, T., and Singh, D.K. 2020, Geochemical characteristics of the Late Cretaceous radiolarian cherts from North Andaman Island, Bay of Bengal, India. Journal of Earth System Science, v. 129, pp. 103. doi:10.1007/s12040-020-1368-2

Jan, M.Q., and Windley, B.F., 1990, Chromian spinel-silicate chemistry in ultramafic rocks of the Jijal complex, northwest Pakistan. Journal of Petrology, v. 31, pp. 667-715, doi:10.1093/petrology/31.3.667

Johnson, M.C., and Plank, T., 1999, Dehydration and melting experiments constrain the fate of subducted sediments, Geochemistry Geophysics Geosystems, v. 1, pp. 1-26. doi:10.1029/1999GC000014

Kamenetsky, V.S., Crawford, A.J., and Meffre, S., 2001, Factors controlling chemistry of magmatic spinel: an empirical study of associated olivine, $\mathrm{Cr}$-spinel and melt inclusions from primitive rocks. Journal of Petrology, v. 42, pp. 655-671. doi:10.1093/petrology/42.4.655

Kelley, K.A., Plank, T., Grove, T.L., Stolper, E.M., Newman, S., and Hauri, E., 2006, mantle melting as a function of water content beneath backarc basins, Journal of Geophysical Research, pp. 111, B09208. doi: $10.1029 / 2005 J B 003732$

Lagabrielle, Y., Guivel, C., Maury, R., Bourgois, J., Fourcade, S., and Martin, H., 2000. Magmatic-tectonic effects of high thermal regime at the site of active ridge subduction: The Chile triple junction model. Tectonophysics, v. 326, pp. 255-268. doi:10.1016/S0040-1951(00)00124-4

Langmuir, C.H., Bezos, A., Escrig, S., and Parman, S. W., 2006, Chemical systematics and hydrous melting of the mantle in back-arc basins, in Back-Arc Spreading Systems : Geological, Biological, Chemical, and Physical Interactions, edited by D. M. Christie et al., pp. 87-146, Geophysical Monograph Series, Washington, D.C. doi:10.1029/166GM07

Leake, B.E., Woolley, A.R., Arps, C.E.S., Birch, W.D., Gilbert, M.C., Grice, J.D., Hawthorne, F.C., Kato, A., Kisch, H.J., Krivovichev, V.G., Linthout, K., Laird, J., Mandarino, J.A., Maresch, W.V., Nickel, E.H., Rock, N.M.S., Schumacher, J.C., Smith, D.C., Stephenson, N.C.N., Ungaretti, L., Whittaker, E.J.W., and Youzhi, G., 1997, Nomenclature of amphiboles: report of the subcommittee on amphiboles of the International Mineralogical Association, Commission on new minerals and mineral names. Canadian Mineralogist, v. 35, pp. 219-246.

Leterrier, J., Maury, R.C., Thonon, P., Girard, D., and Marechal, M., 1982, Clinopyroxene composition as a method of identification of the magmatic affinities of paleovolcanic series. Earth and Planetary Science Letters, v. 59, pp. 139-154. doi:10.1016/0012-821X(82)90122-4

Ling, H.Y., Chandra, R., and Karkare, S.G., 1996, Tectonic significance of Eocene and Cretaceous radiolaria from South Andaman Island, northeast Indian Ocean. Island Arc, v. 5, pp. 166-179. doi:10.1111/j.14401738.1996.tb00023.x
Lister, G., and Forster, M., 2009, Tectonic mode switches and the nature of orogenesis. Lithos, v. 113, pp. 274-291. doi:10.1016/j.lithos.2008.10.024

Liu, F., Dilek, Y., Xie, Y., Yang, J., and Lian, D., 2018, Melt evolution of upper mantle peridotites and mafic dikes in the northern ophiolite belt of the western YarlungZangbo suture zone (southern Tibet). Lithosphere, v. 10, pp. 109-132. doi:10.1130/L689.1

Macdonald, R., Hawkesworth, C.J., and Heath, E., 2000, The Lesser Antilles volcanic chain: a study in arc magmatism. Earth Science Reviews, v. 49, pp. 1-76. doi:10.1016/S0012-8252(99)00069-0

Manning, C.E., 2004, The chemistry of subduction-zone fluids, Earth Planetary Science Letters, v. 223, pp. 1-16. doi:10.1016/j.eps1.2004.04.030

Masuda, H., and Fryer, P., 2015, Geochemical Characteristics of Active Backarc Basin Volcanism at the Southern End of the Mariana Trough. In: Ishibashi J., Okino K., Sunamura M. (Eds) Subseafloor Biosphere Linked to Hydrothermal Systems. Springer, Tokyo. doi:10.1007/9784-431-54865-2 21

McCulloch, M.T., and Gamble, J.A., 1991, Geochemical and geodynamical constraints on subduction zone magmatism, Earth and Planetary Science Letters, v. 102, pp. 358-374. doi:10.1016/0012-821X(91)90029-H

McKenzie, D., and O'Nions, R.K., 1991, Partial melt distributions of rare earth element concentrations. Journal of Petrology, v. 32, pp. 1021-1091. doi:10.1093/petrology/32.5.1021

Metcalf, R.V., and Shervais, J.W., 2008, Suprasubduction-zone ophiolites: Is there really an ophiolite conundrum? In: Wright, J.E., Shervais, J.W., (Eds), Ophiolites, arcs, and batholiths, a tribute to Cliff Hopson, Geological Society of America Special Publication, v. 438, pp. 191-222. doi:10.1130/2008.2438(07)

Miyashiro, A., 1973, The Troodos ophiolitic complex was probably formed in an island arc. Earth and Planetary Science Letters, v. 19, pp. 218-224. doi:10.1016/0012-821X(73)90118-0

Moghadam, H.S., and Stern, R.J., 2011, Geodynamic evolution of Upper Cretaceous Zagros ophiolites: formation of oceanic lithosphere above a nascent subduction zone. Geological Magazine, v. 148, pp.762-801. doi:10.1017/S0016756811000410

Morimoto, N., 1988, Nomenclature of pyroxenes: Mineralogy and Petrology. v. 39, pp. 55-76. doi:10.1007/BF01226262

Morimoto, N., 1989, Nomenclature of pyroxenes. Canadian Mineralogist, v. 27 , pp. $143-156$.

Nakakuki, T., and Mura, E., 2013, Dynamics of slab roll-back and induced back-arc basin formation. Earth and Planetary Science Letters, v. 361, pp. 287-297. doi:10.1016/j.eps1.2012.10.031t

Nicolas, A., 1989, Structure of Ophiolites and Dynamics of Oceanic Lithosphere. Kluwer Academic Publishers, Netherlands, pp 367.

Nimis, P., 1995, A clinopyroxene geobarometer for basaltic systems based on crystal structure modeling. Contributions to Mineralogy and Petrology, v. 121, pp. 115-125, doi:10.1007/s004100050093

Nimis, P., 1999, Clinopyroxene geobarometry of magmatic rocks. Part 2. Structural geobarometers for basic to acid, tholeiitic and mildly alkaline magmatic systems. Contributions to Mineralogy and Petrology, v.135, pp. 62-74. doi:10.1007/s004100050498

Nimis, P., and Taylor, W.R., 2000, Single-clinopyroxene thermobarometry for garnet peridotites: part I. Calibration and testing of a Cr-in-Cpx barometer and an enstatite-in-Cpx thermometer. Contributions to Mineralogy and Petrology, v. 139, pp. 541-554, doi:10.1007/s004100000156

Ordóñez-Calderón, J.C., Polat, A., Fryer, B., Gagnon, J., Raith, J.G., and Appel, P., 2008, Evidence for HFSE and REE mobility during calc-silicate metasomatism, Mesoarchean ( $3075 \mathrm{Ma})$ Ivisaartoq greenstone belt, southern West Greenland. Precambrian Research, v. 161, pp. $317-$ 340. doi:10.1016/j.precamres.2007.09.004

Özdamar, S., 2016, Geochemistry and geochronology of late Mesozoic volcanic rocks in the northern part of the Eastern PontideOrogenic belt (NE Turkey): implications for the closure of the Neotethyan Ocean. Lithos, v. 248-251, pp. 240-256. doi:10.1016/j.lithos.2016.01.007

Pal, T., Chakraborty, P.P., Dutta, G.T., and Singh, C.D., 2003, Geodynamic evolution of the outer-arc - forearc belt in the Andaman Islands, the 
central part of the Burma- Java subduction complex. Geological Magazine, v. 140, pp. 289-307. doi:10.1017/S0016756803007805

Pal, T., 2011, Petrology and geochemistry of the Andaman ophiolite: meltrock interaction in a suprasubduction-zone setting. Journal of the Geological Society, v. 168, pp. 1031-1045. doi:10.1144/0016-76492009-152

Pal, T., 2020, Structural Imprints of Andaman Accretionary Prism and Its Tectonic Relation with Ophiolite Belt of Indo-Burma Ranges. In: T. K. Biswal et al. (eds.), Structural Geometry of Mobile Belts of the Indian Subcontinent, Society of Earth Scientists Series, pp. 111-130. doi:10.1007/ 978-3-030-40593-9 5

Pearce, J.A., and Norry, M.J., 1979, Petrogenetic implications of Ti, Zr, Y, and $\mathrm{Nb}$ variations in Intrusive Rocks. Contributions to Mineralogy and Petrology, v. 69, pp. 33-47. doi:10.1007/BF00375192

Pearce, J.A., 1983, The role of subcontinental lithosphere in magma genesis at active continental margins. In: Hawkesworth, C.J., and Norry, M.J. (Eds.), Continental basalt and mantle xenoliths. Nantwich Cheshire, Shiva Publication, pp. 230-249.

Pearce, J.A., Ernewein, M., Bloomer, S.H., Parson, L.M., Murton, B.J., and Johnson, L.E., 1994, Geochemistry of Lau basin Volcanic rocks: influence of ridge segmentation and arc proximity, in Millie, J.L., (Eds.), Volcanism associated with Extension at Consuming Plate Margin: Geological Society of London Special Publication, v. 81, pp. 53-75. doi:10.1144/GSL.SP.1994.081.01.04

Pearce, J.A., Stern, R.J., Bloomer, S.H., and Fryer, P., 2005, Geochemical mapping of the Mariana Arc-Basin System: Implications for the nature and distribution of subduction components: Geochemistry Geophysics Geosystems 6, Q07006. doi:10.1029/2004GC00089

Pearce, J.A., and Stern, R.J., 2006, origin of back-arc basin magmas: trace element and isotope perspectives. In: Christie, D., (Eds.), Back arc spreading systems: geological, biological, chemical and physical interactions, Geophysical Monograph Series, v. 166, pp. 63-86. doi:10.1029/166GM06

Pearce, J.A., 2008, Geochemical fingerprinting of oceanic basalts with applications to ophiolite classification and the search for Archean oceanic crust. Lithos, v. 100, pp. 14-48. doi:10.1016/j.lithos.2007.06.016

Pedersen, R.B., Searle, M.P., Carter, A., and Bandopadhyay, P.C., 2010, U$\mathrm{Pb}$ zircon age of the Andaman ophiolite: implications for the beginning of subduction beneath the Andaman-Sumatra arc. Journal of the Geological Society, v. 167, pp. 1105-1112. doi:10.1144/0016-76492009-151

Piauilino, P.F., Hauser, N., and Dantas, E.L., 2019, From passive margin to continental collision: Geochemical and isotopic constraints for E-MORB and OIB-like magmatism during the Neoproterozoic evolution of the southeast Brasília Belt. Precambrian Research, pp. 105-345. doi:10.1016/ j.precamres.2019.105345

Pirnia, T., Saccani, E., Torabi, G., Chiari, M., Gorican, S., and Barbero, E., 2020, Cretaceous tectonic evolution of the Neo-Tethys in Central Iran: Evidence from petrology and age of the Nain-Ashin ophiolitic basalts. Geoscience Frontiers, v. 11, pp. 57-81. doi:10.1016/j.gsf.2019.02.008

Plunder, A., Bandyopadhyay, D., Ganerød, M., Advokaat, E.L., Ghosh, B., Pinaki Bandopadhyay, P., and van Hinsbergen D.J.J., 2020, History of subduction polarity reversal during arc-continent collision: constraints from the Andaman Ophiolite and its metamorphic sole. doi:10.1029/ 2019TC005762

Polat, A., Kerrich, R., and Wyman, D.A., 1999, Geochemical diversity in oceanic komatiites and basalts from the late Archaean Wawa greenstone belt, Superior Province, Canada: trace element and Nd isotope evidence for a heterogeneous mantle. Precambrian Research, v. 94, pp. 139-173. doi:10.1016/S0301-9268(98)00110-7

Pouchou, J.L., and Pichoir, F., 1987, Basic expressions of PAP computation for quantitative EPMA, Proceedings of ICXOM 11, Ontario, pp. 249-253.

Purohit, K.K., Mukherjee, P.K., Saini N K., Khanna, P.P., and Rathi, M.S., 2006, Geochemical survey of stream sediments from upper parts of Alaknanda, Mandakini, Bhilangana and Bhagirathi catchments, Garhwal Himalaya; Himalayan Geology, v. 27, pp. 31-39.

Putirka, K., Johnson, M., Kinzler, R., Longhi, J., and Walker, D., 1996,
Thermobarometry of mafic igneous rocks based on clinopyroxene-liquid equilibria, 0-30 kbar. Contribution to Mineralogy and Petrology, v. 123, pp. 92-108. doi:10.1007/s004100050145

Putirka, K.D., Mikaelian, H., Ryerson, F., and Shaw, H., 2003, New clinopyroxene-liquid thermobarometers for mafic, evolved, and volatile-bearing lava compositions, with applications to lavas from Tibet and the Snake River Plain, Idaho. American Mineralogist, v. 88, pp. 1542-1554. doi:10.2138/am-2003-1017

Putirka, K.D., 2008, Thermometers and barometers for volcanic systems. In: Putirka K.D., Tepley FJ III (Eds), Minerals, Inclusions and Volcanic Processes. Mineralogical Society of America and Geochemical Society, Reviews in Mineralogy and Geochemistry, v. 69, pp. 61-120. doi:10.2138/rmg.2008.69.3

Qian, X., Wang, Y., Feng, Q., Wei, ZiJ., Zhang, Y., and Chonglakmani, C., 2016, Petrogenesis and tectonic implication of the Late Triassic post collisional volcanic rocks in Chiang Khong, NW Thailand. Lithos, v. 248-251, pp. 418-431. doi:10.1016/j.lithos.2016.01.024

Rasool, Q.A., Ramanujam, N., and Biswas, S.K., 2015, Petrology and Geochemistry of Gabbros from the Andaman Ophiolite: Implications for their Petrogenesis and Tectonic Setting. Journal of Geology and Geophysics, v. 4, pp. 6. doi:10.4172/2381-8719.1000226

Ribeiro, J.M., Stern, R.J., Kelley, K.A., Martinez, F., Ishizuka, O., Manton, W. I., and Ohara, Y., 2013, Nature and distribution of slab-derived fluids and mantle sources beneath the Southeast Mariana forearc rift, Geochemistry Geophysics Geosystems, v. 14, pp. 4585-4607. doi:10.1002/ ggge. 20244

Ray, K.K., Sengupta, S., and Van Den Hul, H.J., 1988, Chemical characteristics of volcanic rocks from Andaman ophiolite, India. Journal of Geological Society London, v. 145, pp. 393-400. doi:10.1144/gsjgs. 145.3.0393

Robinson, J.A.C., and Wood, B.J., 1998, The depth of the spinel to garnet transition at the peridotite solidus, Earth and Planetary Science Letters, v. 164, pp. 277-284. doi:10.1016/S0012-821X(98)00213-1

Rolland, Y., Galoyan, G., Bosch, D., Sosson, M., Corsini, M., Fornari, M., and Verati, C., 2009, Jurassic Back-arc and hot-spot related series in the Armenian ophiolites-Implications for the obduction process. Lithos, v. 112, pp. 163-187. doi:10.1016/j.lithos.2009.02.006

Rooney, T.O., 2010, Geochemical evidence of lithospheric thinning in the southern Main Ethiopian Rift, Lithos, v. 117, pp. 33-48. doi:10.1016/ j.lithos.2010.02.002

Ross, P.S., and Bédard, J.H., 2009, Magmatic affinity of modern and ancient subalkaline volcanic rocks determined from trace-element discriminant diagrams. Canadian Journal of Earth Sciences, v. 46, pp. 823-839. doi:10.1139/E09-054

Rudnick, R.L., and Gao, S., 2003, The composition of the continental crust. In: Rudnick, R.L., (Eds.) The crust, Elsevier, Amsterdam, v. 3, pp.1-64. doi:10.1016/B0-08-043751-6/03016-4

Saccani, E., Photiades, A., and Beccaluva, L., 2008a, petrogenesis and tectonic significance of IAT magma-types in the Hellenideophiolites as deduced from the Rhodianiophiolites (Pelagonian zone, Greece). Lithos, v. 104, pp. 71-84. doi:10.1016/j.lithos.2007.11.006

Saccani, E., Bortolotti, V., Marroni, M., Pandolfi, L., Photiades, A., and Principi, G., 2008b, The Jurassic association of back-arc basin ophiolites and calc-alkaline volcanics in the Guevgueli Complex (northern Greece): implication for the evolution of the Vardar Zone. Ofioliti, v. 33, pp. 209-227. doi:10.4454/OFIOLITI.V33I2.370

Sachin, R., Verma, S., and Pal, T., 2017, Petrochemical and PetrotectonicCharacterisation of Ophiolitic Volcanics from Great Nicobar Island Andaman-Sumatra Belt. Journal Geological Society of India, v. 90, pp. 85-92. doi:10.1007/s12594-017-0667-y

Saha, A., Dhang, A., Ray, J., Charkraborty, S., and Moecher, D., 2010, Complete preservation of ophiolite suite from south Andaman, India: a mineral-chemical perspective. Journal of Earth Sciences, v. 105, pp. 300-319. doi:10.1007/s12040-010-0017-6

Saha, A., Santosh, M., Ganguly, S., Manikyamba, C., Ray, J., and Dutta, J., 
2018, Geochemical cycling during subduction initiation: Evidence from serpentinized mantle wedge peridotite in the south Andaman ophiolite suite. Geoscience Frontiers, v. 9, pp. 1755-1775. doi:10.1016/j.gsf.2017. 12.017

Saini, N.K., Mukherjee, P.K., Rathi, M.S., Khanna, P.P., and Purohit, K.K., 1998, A new geochemical reference sample of granite (DG-H) from Dalhousie, Himachal Himalaya. Journal of the Geological Society of India, v. 52, pp. 603-606.

Saini, N.K., Mukherjee, P.K., Rathi, M.S., and Khanna, P.P., 2000, Evaluation of energy-dispersive $\mathrm{x}$-ray fluorescence spectrometry in the rapid analysis of silicate rocks using pressed powder pellets. X-ray Spectrometry, v. 29, pp. 166-172.

Saini, N.K., Mukherjee, P.K., Khanna, P.P., and Purohit, K.K., 2007, A proposed amphibolite reference rock sample (AM-H) from Himachal Pradesh. Journal of the Geological Society of India, v. 69, pp. 799-802.

Sarma, S.D., Jafri S.H., Flecher, I.R., and Mcnaughton N.J., 2010, Constraints on the Tectonic Setting of the Andaman Ophiolites, Bay of Bengal, India, from SHRIMP U-Pb Zircon Geochronology of Plagiogranite. Journal of Geology, v. 118, pp. 691-697.

Sandeman, H.A., Hanmer, S., Tella, S., Armitage, A.A., Davis, W.J., and Ryand, J.J., 2006, Petrogenesis of Neoarchaean volcanic rocks of the MacQuoid supracrustal belt: A back-arc setting for the northwestern Hearne subdomain, western Churchill Province. Canada. Precambrian Research, v. 144, pp. 140-165. doi:10.1016/j.precamres.2005.11.001

Saunders, A.D., and Tarney, J., 1979, The geochemistry of basalts from a back-arc spreading centre in the east Scotia Sea. Geochimica et Cosmochimica Acta, v. 43, pp. 555-572. doi:10.1016/0016-7037(79)90165-0

Scarrow, J.H., and Cox, K.G., 1995, Basalts Generated by Decompressive Adiabatic Melting of a Mantle Plume: a Case Study from the Isle of Skye, NW Scotland. Journal of Petrology, v. 36, pp. 3-22. doi:10.1093/ petrology/36.1.3

Sdrolias, M., Müller, R.D., Mauffret, A., and Bernardel, G., 2004, Enigmatic formation of the Norfolk Basin, SW Pacific: a plume influence on back-arc extension. Geochemistry, Geophysics, Geosystems, v. 5, Q06005. doi:10.1029/2003GC000643

Sdrolias, M., and Muller, R.D., 2006, Control on back arc formation. Geochemistry, Geophysics, Geosystem, v. 7, Q04016. doi:10.1029/ 2005GC001090

Shastry, A., Srivastava, R.K., Chandra, R., and Jenner, G.A., 2002, Geochemical characteristics and genesis of oceanic plagiogranites associated with south Andaman Ophiolite Suite, India: a late stage silicate liquid immiscible product. Journal of Geological Society of India, v. 59, pp. 233-241.

Shaw, D.M., 1970, Trace element fractionation during anatexis. Geochimica et Cosmochimica Acta, v. 34, pp. 237-243. doi:10.1016/00167037(70)90009-8

Shervais, J.W., 1982, Ti-V plots and the petrogenesis of modern and ophiolite lavas: Earth and Planetary Science Letters, v. 59, pp. 101-118. doi:10.1016/0012-821X(82)90120-0

Shinjo, R., Chung, S.L., Kato, Y., and Kimura, M., 1999, Geochemical and $\mathrm{Sr}-\mathrm{Nd}$ isotopic characteristics of volcanic rocks from the Okinawa Trough and Ryukyu Arc: Implications for the evolution of a young, intracontinental back arc basin. Journal of Geophysical Research, v. 104, pp. 10591-10608. doi:10.1029/1999JB900040

Sloan, R.A., Elliott, J.R., Searle, M.P., and Morley, C.K., 2017, In Barber, A.J., Zaw, K., Crow, M. J., (Eds.), Chapter 2. Active tectonics of Myanmar and the Andaman Sea, Memoirs London: Geological Society, pp 19-52. doi:10.1144/M48.2

Slovenec, D.A., Lugović, B., and Vlahović, I., 2010, Geochemistry, petrology and tectonomagmatic significance of basaltic rocks from the ophiolite mélange at the NW External-Internal Dinarides junction (Croatia). Geologica Carpathica, v. 61, pp. 273-294. doi:10.2478/v10096-010-0016-1

Smith, J.V., 1974a, Feldspar minerals: Crystal structures and physical properties. Heidelberg, N.Y., Berlin, Springer-Verlag, v. 1, pp. 627.

Smith, J.V, 1974b, Feldspar minerals: Chemical and textures properties.
Heidelberg, N.Y., Berlin, Springer-Verlag, v. 2, pp. 692.

Spear, F.S., 1993, Metamorphic Phase Equilibria and Pressure-Temperature-Time Paths. Monograph 1. Mineralogical Society of America: Washington, DC, pp. 799.

Srivastava, R.K., Chandra, R., and Shastry, A.K., 2004, High Ti type NMORB parentage of basalts from the south Andaman ophiolite suite, India. Journal of Earth System Science, v. 113, pp. 605-618. doi:10.1007/ BF02704025

Stakes, D.S., and Franklin, J.M., 1994, Petrology of Igneous Rocks at Middle Valley, Juan de Fuca Ridge. In: Mottl, M.J., Davis, E.E., Fisher, A.T., et al. (Eds.), Proceedings of the Ocean Drilling Program, Scientific Results, College Station, Texas, v. 139, pp. 79-102. doi:10.2973/odp.proc.sr. 139.212.1994

Stracke, A., Bizimis, M., and Salters, V.J.M., 2003, Recycling oceanic crust: quantitative constraints. Geochemistry, Geophysics, Geosystem, v. 4, 8003. doi: $10.1029 / 2001 \mathrm{GC} 000223$

Sun, S.S., and McDonough, W.F., 1989, Chemical and isotopic systematics of oceanic basalts: Implications for mantle composition and processes. In: Sounders. A. S, and Norrey, M. J, (Eds.), Magmatism in the Ocean Basins. Geological Society London Special Publications, v. 42, pp. 313-345. doi:10.1144/GSL.SP.1989.042.01.19

Sun, P., Niu, Y., Guo, P., Duan, M., Wang, X., Gong, H., and Xiao, Y., 2020, The lithospheric thickness control on the compositional variation of continental intraplate basalts: A demonstration using Cenozoic basalts and clinopyroxene megacrysts from Eastern China. Journal of Geophysical Research. doi:10.1029/2019JB019315

Tankut, A., Dilek, Y., and Önen, P., 1998, Petrology and geochemistry of the Neotethyan volcanism as revealed in the Ankara melange, Turkey. Journal of Volcanology and Geothermal Research, v. 85, pp. 265-284.

Taylor, S.R., and McLennan, S.M., 1985, The Continental Crust: its Composition and Evolution: An examination of the Geochemical Record Preserved in Sedimentary Rocks. Blackwell Scientific Publication, Oxford, pp. 312.

Thirlwall, M.F., Smith, T.E., Graham, A.M., Theodorou, N., Hollings, P., Davidson, J.P., and Arculus R.J., 1994, High field strength element anomalies in arc lavas: source or process? Journal of Petrology, v. 35, pp. 819-838. doi:10.1093/petrology/35.3.819

Trua, T., Serri, G., and Marani, M.P., 2007, Geochemical features and geodynamic significance of the southern Tyrrhenian back arc basin, in Beccaluva, L., Bianchini, G., and Wilson, M., eds., Cenozoic Volcanism in the Mediterranean Area: Geological Society of America Special Paper v. 418, p. 221-233. doi:10.1130/2007.2418(11)

VanderLaan, S.R., Arculus, R.J., Pearce, J.A., and Murton, B.J., 1992, Petrography, Mineral Chemistry, and Phase Relations of the Basement Boninite Series of site 786, Izu-Bonin Forearc. In: Fryer, P., Pearce, J.A., Stokking, L.B., et al. (Eds.), Proceedings of the Ocean Drilling Program, Scientific Results, 125, College Station, Texas, pp. 171-201. doi:10.2973/odp.proc.sr.125.139.1992

Vohra, C.P, Haldar, D., and Ghosh, R. A.K., 1989, The Andaman-Nicobar Ophiolite Complex and associated mineral resources-current appraisal. In: Ghose, N. C, (Eds.), Phenerozoic Ophiolite of India. Sumna Publication., Patna, pp. 281-315.

Vogt, K., Gerya, T.V., and Castro, A., 2012, Crustal growth at active continental margins: Numerical modeling. Physics of Earth and Planet. Interior, v. 192-193, pp. 1-20. doi:10.1016/j.pepi.2011.12.003

Wakabayashi, J., and Dilek, Y., 2003, What constitutes "emplacement" of an ophiolite? Mechanisms and relationship to subduction initiation and formation of metamorphic soles. In: Dilek, Y. and Robinson, P.T. (Eds), Ophiolites in Earth History, Geological Society of London, Special Publication, v. 218, pp. 427-448. doi:10.1144/GSL.SP.2003.218.01.22

Wendt, J.I., Regelous, M., Collerson, K.D., and Ewart, A. 1997, Evidence for a contribution from two mantle plumes to island-arc lavas from northern Tonga. Geology, v. 25, pp. 611-614. doi:10.1130/00917613(1997)025<0611:EFACFT>2.3.CO;2

Winchester, J.A., and Floyd, P.A., 1977, Geochemical discrimination of 
different magma series and their differentiation products using immobile elements. Chemical Geology, v. 20, pp. 325-343. doi:10.1016/00092541(77)90057-2

Workman, R.K., and Hart, S.R., 2005, Major and trace element composition of the depleted MORB mantle (DMM). Earth and Planetary Science Letter, v. 231, pp. 53-72. doi:10.1016/j.epsl.2004.12.005

Yuan, C., Sun, M., Zhou, M.F., Xiao, W., and Zhou, H., 2005, Geochemistry and petrogenesis of the Yishak Volcanic Sequence, Kudi ophiolite, West Kunlun (NW China): implications for the magmatic evolution in a subduction zone environment. Contributions to Mineralogy and Petrol-

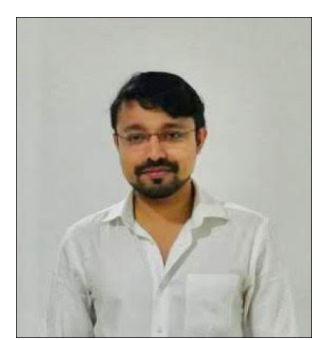

Salim Akhtar He is a research scholar in the Department of Geology, University of Delhi, India. He is currently working on understanding the genesis of Andaman Island ophiolites in particular and other ophiolite occurrences of India. His research focuses on advanced geochemical modelling to understand the magma source and geochronology for regional geodynamic correlation.

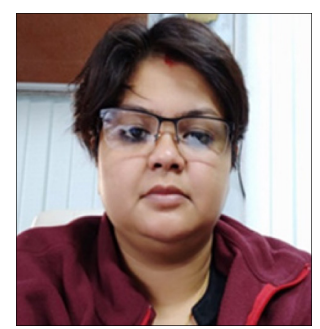

Ashima Saikia She is currently working as an Assistant Professor in the Department of Geology, University of Delhi. She has more than ten years of teaching experience in crystallography, mineralogy and igneous petrology to her credit. A trained experimental petrologist, her research interests include geochemical modelling for understanding ophiolite genesis, constraining crustal evolution based on magmatic rocks using mineralogy, geochemistry and geochronology for its implications on regional geodynamics. She has extensively published work on the microdomain characterisation of magmatic textural features to understand magma mixing processes. ogy, v. 150, pp. 195-211. doi:10.1007/s00410-005-0012-0

Zhang, Z.M., Shen, K., Sun, W.D., Liu, Y.S., Liou, J.G., Shi, C., and Wang, J.L., 2008, Fluids in deeply subducted continental crust: petrology, mineral chemistry and fluid inclusion of UHP metamorphic veins from the Sulu orogen, eastern China. Geochimica et Cosmochimica Acta, v. 72, pp. 3200-3228. doi:10.1016/j.gca.2008.04.014

Zhu, H., Du, L., Li, X., Zhang, Z., and Sun, W., 2020, Calcium isotopic fractionation during plate subduction: Constraints from back-arc basin basalts. Geochemica et Cosmochimica Acta, v. 270, pp. 379-393. doi:10.1016/j.gca.2019.12.004

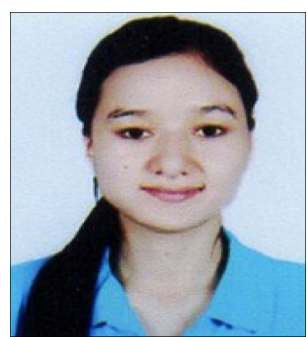

Priyanka Negi She is a research scholar in the Department of Geology, University of Delhi, India. Her research interests include igneous geochemistry, mineralogy and geotectonic evolution. Currently working on mafic and ultramafic rock associations of Indian terrain.

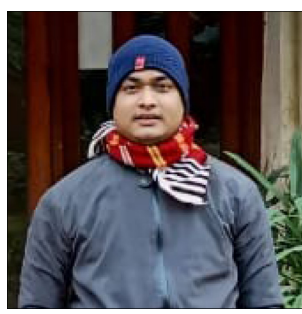

Bikas Jyoti Kalita He is a research scholar in the Department of Geology, University of Delhi, India, interested in various aspects of igneous petrogenesis. 